Article

\title{
Coniferous-Broadleaf Mixture Increases Soil Microbial Biomass and Functions Accompanied by Improved Stand Biomass and Litter Production in Subtropical China
}

\author{
Wenxiang $\mathrm{Wu}^{1}{ }^{1}$, Xiaoguo Zhou ${ }^{1}$, Yuanguang Wen ${ }^{1,2, *}$, Hongguang Zhu ${ }^{1}$, Yeming You ${ }^{1}$, \\ Zhiwei Qin ${ }^{3}$, Yunchou Li ${ }^{1}$, Xueman Huang ${ }^{1}$, Li Yan ${ }^{1} \mathbb{D}$, Haiyan $\mathrm{Li}^{4}$ and Xiaoqiong $\mathrm{Li}^{1}$ \\ 1 Guangxi Key Laboratory of Forest Ecology and Conservation, Forestry College, Guangxi University, \\ 100 Daxuedong Road, Nanning 530004, China; wenxiangwu@foxmail.com (W.W.); \\ xgzhou2014@126.com (X.Z.); xu980307@163.com (H.Z.); youyeming@163.com (Y.Y.); \\ franklee1235@163.com (Y.L.); huangxm168168@163.com (X.H.); 13647886805@163.com (L.Y.); \\ lixiaoqiong100@163.com (X.L) \\ 2 Guangxi Youyiguan Forest Ecosystem National Research Station, Pingxiang 532600, China \\ 3 Guangxi Laibin Forest Inventory and Planning Institute, 289 Yaru Road, Liuzhou 545001, China; \\ qzw118590578@163.com \\ 4 Guangxi Yulin Forest Inventory and Planning Institute, 332 Renmin East Road, Yulin 537000, China; \\ lihaiyan6084@foxmail.com \\ * Correspondence: wenyg@263.net; Tel.: +86-0771-3271-048
}

Received: 16 August 2019; Accepted: 2 October 2019; Published: 6 October 2019

\begin{abstract}
Although the advantages of multi-species plantations over single-species plantations have been widely recognized, the mechanisms driving these advantages remain unclear. In this study, we compared stand biomass, litter production and quality, soil properties, soil microbial community, and functions in a Pinus massoniana Lamb. and Castanopsis hystrix Miq. mixed plantation and their corresponding mono-specific plantations after 34 years afforestation in subtropical China. The results have shown that a coniferous-broadleaf mixture created significantly positive effects on stand biomass, litter production, soil microbial biomass, and activities. Firstly, the tree, shrub and herb biomass, and litter production were significantly higher in the coniferous-broadleaf mixed plantation. Secondly, although the concentrations of soil organic carbon (SOC) and total nitrogen (TN) were lower in the mixed stand, the concentrations of soil microbial biomass carbon (MBC), and nitrogen (MBN), along with MBC-to-SOC and MBN-to-TN ratio, were significantly higher in mixed stands with markedly positive admixing effects. We also found higher carbon source utilization ability and $\beta-1,4-\mathrm{N}$-acetylglucosaminidase, urease and acid phosphatase activities in mixed stands compared with the mono-species stands. Our results highlight that establishment of coniferous-broadleaf mixed forests may be a good management practice as coniferous-broadleaf mixture could accumulate higher stand biomass and return more litter, resulting in increasing soil microbial biomass and related functions for the long term in subtropical China.
\end{abstract}

Keywords: coniferous-broadleaf mixture; soil microbial biomass; extracellular enzymes; phospholipid fatty acids (PLFA); carbon source utilization ability

\section{Introduction}

Planted forests have been rapidly expanding around the world to meet the ever-growing demand for timber and other ecosystem services while avoiding excessive harvesting of natural forests $[1,2]$. Most planted forests are monospecific plantations. In China, $85 \%$ of the country's planted forests are 
monospecific plantations as reported [3]. However, there are serious concerns regarding monospecific plantations, including stand productivity decrease [4], soil quality degradation [5], and serious exotic plant invasion (e.g., Eucalyptus plantations) [6]. In contrast, multi-species plantations often have higher biodiversity, higher productivity, and better soil quality than single-species plantations [7-9]. Theoretically, higher productivity in multi-species compared to single-species plantations can only be expected when species interactions in the multi-species plantations increase the efficiency of resource use or one species increases the supply of a resource [10]. However, interactions between species growing in mixtures, e.g., competition, competitive reduction, and facilitation [11] are often dynamic, changing through space and time as resource availability or climatic conditions change [12,13]. Therefore, it is necessary to understand how tree species interact in mixed plantations and to further develop these systems to minimize competition while maximizing both wood production and other ecosystem services in the long term.

Masson pine (Pinus massoniana Lamb.) and Castanopsis hystrix Miq. are two afforestation tree species that are most widely planted in subtropical China, usually making up monoculture plantations. Such monospecific plantations have caused serious ecological concerns, including declines in stand productivity, litter quality, and soil fertility resulting from long-term single litter input, increased pest and disease attack, self-allelopathy, and site degradation [14-16]. To mitigate these disadvantages, mixed P. massoniana and C. hystrix plantations were established about 40 years ago at the Experimental Center of Tropical Forestry, Chinese Academy of Forestry, in subtropical China. At present, the area of these plantations is more than 5000 ha [1]. Previous studies have suggested that mixed plantations of these two genera could lead to more plant species diversity, more productivity, faster litter decomposition rate, and higher carbon stocks compared to monospecific stands $[7,14,16,17]$. Interactions between aboveground plant communities and belowground microbial communities may underlie some of these positive effects, while little is known about these interactions in mixed stands of P. massoniana and C. hystrix.

In general, there are enormously important interactions between the composition of aboveground plant communities and belowground microbial communities in forest ecosystems [18]. Management strategies such as tree species transformation, adding $\mathrm{N}_{2}$-fixing species or broad-leaf species in coniferous monospecific stands may change the amount and chemical composition of litterfall, root mass, and exudates [14,19], then affect soil organic matter quantity and dynamics [8], along with microsite conditions [20]. As a result, these changes may control the composition and functions of the soil microorganisms which acquire carbon from primarily producer-derived organic resources [21]. At the same time, soil microbes are important regulators of plant productivity through the mineralization of, and competition for, nutrients that sustain plant productivity [22]. Moreover, soil microbial diversity and abundance/biomass play key roles in ecosystem sustainability by maintaining essential functions of soil health through carbon and nutrient turnover [23]. Meta-analysis has shown that plant mixtures have increased soil total microbial, bacterial, and fungal biomass across a diverse range of terrestrial ecosystems, and the increase in microbial biomass was more pronounced in older and more diverse mixtures [24]. This may be attributable to higher productivity inducing more carbon and nutrient inputs to the soil in mixtures, benefitting both fungi and bacteria [24,25]. Moreover, different tree species in mixtures produce litter of varying quality, interacting with the rhizosphere and causing microenvironmental changes that affect microbial activity and therefore soil nutrients [26-28]. However, the effects of tree species mixtures on soil microorganisms may change with ecosystem types, environment, and time. Whether coniferous-broadleaf mixture increases soil microbial biomass and activity in subtropical China in long-term afforestation remains unexplored.

In this study, we explored stand biomass, litter, soil physicochemical properties, and soil microbial community structure and function in a mixed P. massoniana and C. hystrix plantation and corresponding single species plantations at an age of 34 years in subtropical China. Our goal was to determine the effects of coniferous-broadleaf mixture on soil microbial communities and functions in long term. We hypothesized that (1) stand biomass, litter production, and quality are higher in the mixed stands 
than those in corresponding monocultures in long term; (2) positive admixing effects on soil microbial biomass and functions are accompanied by improved stand biomass and litter production.

\section{Materials and Methods}

\subsection{Study Sites and Experimental Design}

This study was conducted at the Experimental Center of Tropical Forestry $\left(22^{\circ} 10^{\prime} \mathrm{N}, 106^{\circ} 50^{\prime} \mathrm{E}\right)$, Chinese Academy of Forestry, Pingxiang City, Guangxi Zhuang Autonomous Region, P.R. China. This region belongs to a subtropical monsoon climate zone, and has a humid-to-semi-humid climate with dry-cool (from October to April) and wet-warm seasons (from May to September), according to the variation of precipitation and temperature [29]. The mean annual precipitation is about $1400 \mathrm{~mm}$; most rainfall occurs from April to September. The mean annual temperature is $21^{\circ} \mathrm{C}$. The loamy-textured soil in this area was formed from granitic parent geological material, and is classified as red soil in the Chinese system of soil classification, which is equivalent to an oxisol in the USDA Soil Taxonomy $[8,14]$.

Our study site consisted of a 33 ha plantation of pure C. hystrix $(\mathrm{PCH})$, a 33 ha plantation of pure P. massoniana (PPM), and an 18 ha plantation of mixed C. hystrix and P. massoniana (MIX). Prior to the establishment of the current plantations, the area was covered by a Cunninghamia lanceolata monospecific plantation, which was established in 1958 on a historically deforested hill and clear harvested in 1983. After clearcutting the prior plantations, the PCH, PPM, and MIX plantations were established in 1983 with an initial planting density of 2500 tree ha $^{-1}$ and a 1:1 mixed proportion in the MIX for comparison of tree productivity and the ecological benefits of mixed plantations. Buffer zones of 150-800 m were set up to separate these plantations. These stands had similar soil types, topographies, and management histories.

In June 2017, 34 years after the establishment of the plantations, we randomly established five sample plots $(20 \mathrm{~m} \times 20 \mathrm{~m})$ in each plantation. The five sampling plots within a single experimental stand were well separated, with distances of at least $200 \mathrm{~m}$ between adjacent plots. Elevations of all plots were $530-650 \mathrm{~m}$, and the degree of slopes was 30-39 . The stand density ranged from 355 to 400 tree ha $^{-1}$, and average height from $22 \mathrm{~m}$ to $25 \mathrm{~m}$. The diameter at breast height (DBH) and basal area of MIX was significantly higher than that of PCH and PPM (Table 1).

Table 1. Characteristics of pure Castanopsis hystrix Miq. (PCH) plantation, pure Pinus massoniana Lamb. (PPM) plantation, and mixed C. hystrix and P. massoniana (MIX) plantation (mean \pm standard error; $n=5)$.

\begin{tabular}{|c|c|c|c|c|}
\hline Stand & Density (Tree ha ${ }^{-1}$ ) & Height (m) & DBH (cm) & Basal Area $\left(\mathrm{m}^{2} \mathrm{ha}^{-1}\right)$ \\
\hline $\mathrm{PCH}$ & $355 \pm 15^{a}$ & $23.95 \pm 0.80^{\mathrm{a}}$ & $28.24 \pm 0.97^{b}$ & $23.15 \pm 1.50^{b}$ \\
\hline MIX & $380 \pm 10^{a}$ & $24.52 \pm 0.37^{\mathrm{a}}$ & $34.31 \pm 1.02^{\mathrm{a}}$ & $39.67 \pm 2.27^{\mathrm{a}}$ \\
\hline P. massoniana & $95 \pm 9$ & $22.01 \pm 0.67$ & $26.16 \pm 0.75$ & $5.35 \pm 0.85$ \\
\hline C. hystrix & $285 \pm 15$ & $25.33 \pm 0.39$ & $36.95 \pm 1.63$ & $34.32 \pm 2.91$ \\
\hline PPM & $400 \pm 24^{\mathrm{a}}$ & $23.32 \pm 0.71^{\mathrm{a}}$ & $28.16 \pm 1.04^{b}$ & $26.60 \pm 2.57^{b}$ \\
\hline
\end{tabular}

Different superscripts indicate significant differences among stand types $(p<0.05)$. DBH, diameter at breast height.

\subsection{Stand Biomass Measurements}

Three $2 \mathrm{~m} \times 2 \mathrm{~m}$ subplots and three $1 \mathrm{~m} \times 1 \mathrm{~m}$ subplots were randomly placed in each plot for shrub and herb biomass measurements, respectively, in the wet-warm (July 2017) and dry-cool seasons (January 2018). In each season, shrubs and herbs were destructively harvested and divided into aboveground and belowground parts. All understory vegetation samples were transported to the laboratory and oven-dried at $75{ }^{\circ} \mathrm{C}$ for dry biomass determination $\left(\mathrm{Mg} \mathrm{ha}^{-1}\right)$ [30].

In addition, we measured tree height with a digital clinometer (Vertex IV, Haglöf Inc., Langsele, Sweden) and DBH with a diameter tape of each tree in each plot and in each season. Tree aboveground 
biomass (TAB) and tree belowground biomass (TBB) were calculated by the allometric equations described by You et al. (2018) [7].

\subsection{Litter Production and Quality Measurements}

A litter collector with an effective collection area of $4 \mathrm{~m}^{2}$ was randomly set in each plot. Each litter collector was made with nylon net, with a mesh size of $1 \mathrm{~mm}$, and set $0.5 \mathrm{~m}$ above the ground with PVC (polyvinyl chloride) tube. Litter was collected once a month from August 2017 to July 2018. Litter samples were transported to the laboratory and oven-dried at $75^{\circ} \mathrm{C}$ for production determination $\left(\mathrm{Mg} \mathrm{ha}^{-1}\right)$. Litter organic carbon $\left(\mathrm{OC}_{\text {litter }}\right)$ concentration was determined by the $\mathrm{K}_{2} \mathrm{Cr}_{2} \mathrm{O}_{7}-\mathrm{H}_{2} \mathrm{SO}_{4}$ calefaction procedure [30]. Litter total nitrogen $\left(\mathrm{TN}_{\text {litter }}\right)$, total phosphorus $\left(\mathrm{TP}_{\text {litter }}\right)$, and total potassium ( $\mathrm{TK}_{\text {litter}}$ ) concentrations were measured after heat digestion with $98 \% \mathrm{H}_{2} \mathrm{SO}_{4}$ [31-33].

\subsection{Soil Sampling and Analysis}

Soil samples were also collected in the wet-warm (July, 2017) and dry-cool seasons (January, 2018). In each season, we took eight soil cores systematically arranged at a distance of $5 \mathrm{~m}$ from the plot center in the directions of $0^{\circ}, 45^{\circ}, 90^{\circ}, 135^{\circ}, 180^{\circ}, 215^{\circ}, 270^{\circ}$, and $315^{\circ}$. Each core was taken using an $8.7 \mathrm{~cm}$ inner diameter steel tube at a depth of $0-10 \mathrm{~cm}$ below the soil surface. The eight cores of each plot were mixed to form a composite sample. Each soil sample was divided into two subsamples. One subsample was air-dried to a constant weight and sieved using a $2 \mathrm{~mm}$ sieve for measuring soil properties. The other subsample was sieved to $2 \mathrm{~mm}$ and immediately stored at $-4{ }^{\circ} \mathrm{C}$ for measuring moisture content, soil ammonium nitrogen $\left(\mathrm{NH}_{4}{ }^{+}-\mathrm{N}\right)$, nitrate nitrogen $\left(\mathrm{NO}_{3}{ }^{-}-\mathrm{N}\right)$, microbial biomass carbon (MBC), microbial biomass nitrogen $(\mathrm{MBN})$ concentration, phospholipid fatty acid analysis (PLFA) assays, carbon source utilization ability of the soil microbial communities, and enzyme activity. At the same time, three soil cores $\left(100 \mathrm{~cm}^{3}\right)$ from $0-10 \mathrm{~cm}$ soil layer were sampled from each plot to measure bulk density by the cutting ring method [34].

The soil water content (WC) was measured using a sub-sample dried in oven at $105^{\circ} \mathrm{C}$ until the sample reached a constant weight. The soil temperatures were measured with an LI-8100A Automated Soil Gas Flux System (Li-Cor, Lincoln, NE, USA). Soil pH was measured in a 1:2.5 soil/water suspension using a $\mathrm{pH}$ meter $[8,35]$. Soil organic carbon (SOC) concentration was determined by the $\mathrm{K}_{2} \mathrm{Cr}_{2} \mathrm{O}_{7}-\mathrm{H}_{2} \mathrm{SO}_{4}$ calefaction procedure [31]. Total nitrogen (TN), total phosphorus (TP), and total potassium (TK) concentration were measured after heat digestion with $98 \% \mathrm{H}_{2} \mathrm{SO}_{4}$. TN and TK were measured using the liquid supernatant with a continuous flow analytical system (AA3; SEAL Analytical, Norderstedt, Germany) [31,33] and an atomic absorption spectrometer (ZEENIT 700P; Analytik, Jena, Germany) [32], respectively. TP and AP were determined by Mo-Sb-Vc colorimetry with the liquid supernatant after heat digestion and $\mathrm{HCl}(0.05 \mathrm{M})-\mathrm{H}_{2} \mathrm{SO}_{4}(0.025 \mathrm{M})$, respectively. And available potassium (AK) was determined by atomic absorption spectrometry with $1 \mathrm{M} \mathrm{NH}_{4} \mathrm{OA}_{\mathrm{C}}$. Soil ammonium nitrogen $\left(\mathrm{NH}_{4}{ }^{+}-\mathrm{N}\right)$ and nitrate nitrogen $\left(\mathrm{NO}_{3}{ }^{-}-\mathrm{N}\right)$ were calorimetrically determined in a continuous flow analyzer after $10 \mathrm{~g}$ fresh mass of soil had been extracted in $50 \mathrm{~mL}$ of $2 \mathrm{M} \mathrm{KCl}[8,36]$. The cation exchange capacity (CEC) was determined by $\left[\mathrm{Co}(\mathrm{NH} 3)_{6}\right] \mathrm{Cl}_{3}$ extraction spectrophotometry [37,38].

Soil microbial biomass carbon $(\mathrm{MBC})$ and nitrogen $(\mathrm{MBN})$ were measured by fumigation-extraction, using $0.5 \mathrm{M} \mathrm{K}_{2} \mathrm{SO}_{4}$ as the extraction agent $[39,40]$, with a total organic carbon analyzer (1020A; OI, College Station, TX, USA).

Phospholipid fatty acid analysis (PLFA) assays were employed to analyze soil microbial community structure with freeze-dried soil samples using the procedure developed by Bossio et al. (1998) [41]. The PLFA markers 14:0, 15:0, 17:0, 18:0, 14:1 $\omega 5 \mathrm{c}, 15: 0$ 3OH, 15:1 $\omega 6 \mathrm{c}, 16: 02 \mathrm{OH}, 16: 12 \mathrm{OH}, 16: 1 \omega 9 \mathrm{c}$, 16:1 $\omega 7 c, 18: 1 \omega 7 c, 18: 02 \mathrm{OH}, 18: 1 \omega 5 c$, a15:0, a16:0, a17:0, cy17:0, cy19:0, i14:0, i15:0, i16:0, i17:0, i18:0 and i19:0 were chosen to represent bacteria. Gram-positive (GP) bacteria were represented by a15:0, a16:0, a17:0, i14:0, i15:0, i16:0, i17:0, i18:0, and i19:0; and gram-negative (GN) bacteria were represented by 14:1 $\omega 5$ c, 15:0 3OH, 15:1 $\omega 6 c, 16: 02 \mathrm{OH}, 16: 12 \mathrm{OH}, 16: 1 \omega 7 \mathrm{c}, 16: 1 \omega 9 \mathrm{c}, 18: 02 \mathrm{OH}, 18: 1 \omega 5 \mathrm{c}, \mathrm{cy} 17: 0$, 
cy19:0, and 18:1 $\omega 7 \mathrm{c}[36,42,43]$. Actinobacteria were represented by 10-Me17:0, 10-Me18:0, TBSA, 11-Me18:1 $\omega 7 \mathrm{c}$, and 10-Me16:0 [12,43,44]. Arbuscular mycorrhizal fungi (AMF) were represented by $16: 1 \omega 11 c$, and 16:1 $\omega 5 c$ [35]; and fungi were represented by 18:1 $\omega 9 c, 18: 3 \omega 6 c(6,9,12)$, and 18:2 $\omega 6,9 \mathrm{c}[12,44]$. Other PLFAs, such as 15:0 2OH, 16:0, 17:1 $\omega 8 \mathrm{c}, 18: 0$ iso, and i20:0, were also used for the analysis of the composition of microbial communities.

Carbon source utilization ability of the soil microbial communities was analyzed using BIOLOG ${ }^{\circledR}$ Eco plates (Biolog, Hayward, CA, USA) with fresh soil samples. Each Biolog Eco-plate comprised 96 wells containing triplicates of 31 different carbon sources and a blank [45]. We added $10 \mathrm{~g}$ dry weight equivalent of fresh soil to $90 \mathrm{~mL}$ of $0.85 \%$ sterile saline physiological solution, and shook the mixture for $1 \mathrm{~h}$ on a rotary shaker $(100 \mathrm{rpm})$ at $25^{\circ} \mathrm{C}$. After $10^{-3}$ dilution, we transferred samples containing $150 \mu \mathrm{L}$ of liquid into the 96 wells, and read the optical density (OD) at 590 and $750 \mathrm{~nm}$ with a Microstation $^{\mathrm{TM}}$ reader (Biolog) after 24, 48,72, 96, 120, 144, 168 and $192 \mathrm{~h}$ of incubation [46,47].

Enzyme assays were performed with a fully automatic full-wavelength enzyme labeling apparatus (Infinite M200 Pro; Tecan Inc., Männedorf, Switzerland) using the procedure describe in detail by Saiya-Cork et al. (2002) [48] and Steinauer et al. (2015) [49]. The phenol oxidase and peroxidase assays were colorimetric, using L3,4-dihydroxyphenylalanine (L-DOPA) as the substrate. The colorimetric urease assay used urea as the substrate. The $\alpha$-Glucosidase (AG), $\beta-1,4$-glucosidase (BG), $\beta$-Cellobiosidase (CB), acid phosphatase (APH) and $\beta-1,4-\mathrm{N}$-acetylglucosaminidase (NAG) activities were fluorometric with substrate 4-methylumbelliferyl- $\alpha$-D-glucoside, 4-methylumbelliferyl- $\beta$-D-glucoside, 4-methylumbelliferyl- $\beta$-D-cellobioside, 4-methylumbelliferyl-phosphate, and 4-methylumbelliferyl$\mathrm{N}$-acetyl- $\beta$-D-glucosaminide, respectively.

\subsection{Statistical Analysis}

One-way analyses of variances (ANOVAs) were used to examine the differences of stand biomass, litter production and quality, soil physicochemical properties, soil microbial biomass, soil microbial PLFAs content and functions among PPM, PCH, and MIX plantations in each season. Two-way ANOVAs were used to determine the interaction effects between stand type and season on the above variables. Statistical analyses were performed with SPSS software (ver. 25.0; IBM Corp., Armonk, NY, USA). Significant differences between means were tested by least significant difference (LSD) at the 0.05 level.

In order to evaluate admixing effects on soil microbial biomass, we calculated the relative effects (RE) of mixing species by comparing the observed value (OV) of one variable in mixed plantation with the predicted value (PE) based on the respective mono-specific plantations. RE was calculated by following Wardle et al. (1997) [50]:

$$
\mathrm{RE}=[(\mathrm{OV}-\mathrm{PE}) / \mathrm{PE}] \times 100,
$$

where PE is the mean of the observed value of one variable in respective mono-specific plantations. If RE differs from zero, it would indicate non-additive effects (NAE) of mixing species on soil microbial biomass. Negative and positive deviations from zero are referred to as antagonistic and synergistic effects, respectively. One-sample Student's $t$-tests with $95 \%$ confidence intervals were employed to test whether RE differed significantly from zero.

Redundancy analysis (RDA) was used to determine the relationships among biotic and abiotic factors, and soil microbial composition and functions by CANOCO software for Windows 5 (Biometris-Plant Research international, Wageningen, The Netherlands). In RDA, the relative abundance of individual PLFAs (mole present of the total PLFAs) was used as the response variables, and soil physicochemical properties, litter and stand biomass were used as the explanatory variables [35,51]. We also used RDA to determine the linkage between soil microbial community and functions, including carbon source metabolic function and soil extracellular enzyme activity involved in biogeochemical circulation of carbon, nitrogen, and phosphorus. All data were log-transformed before in the analyses. 
The forward selection procedure in RDA, based on Monte Carlo permutation with 499 iterations, was performed to determine the dominant variables that influenced the composition of individual PLFAs and microbial functions. A significance level of $p<0.05$ was used in all analyses.

\section{Results}

\subsection{Stand Biomass}

Stand type had significant effects on the -above- and below-ground biomass of trees, shrubs and herbs (Table S1; Figure 1). TAB, TBB, shrub aboveground biomass (SAB), shrub belowground biomass (SBB), and herb aboveground biomass (HAB) in MIX were significantly higher than those in $\mathrm{PCH}$ and PPM in both the dry-cool and wet-warm seasons (Figure 1a-e). Except for HAB, season had no significant effects on the tested biomass variables. Moreover, significant interaction effects between stand type and season only found on HAB and HBB. These results supported our first hypothesis that tree species mixture increased stand biomass.

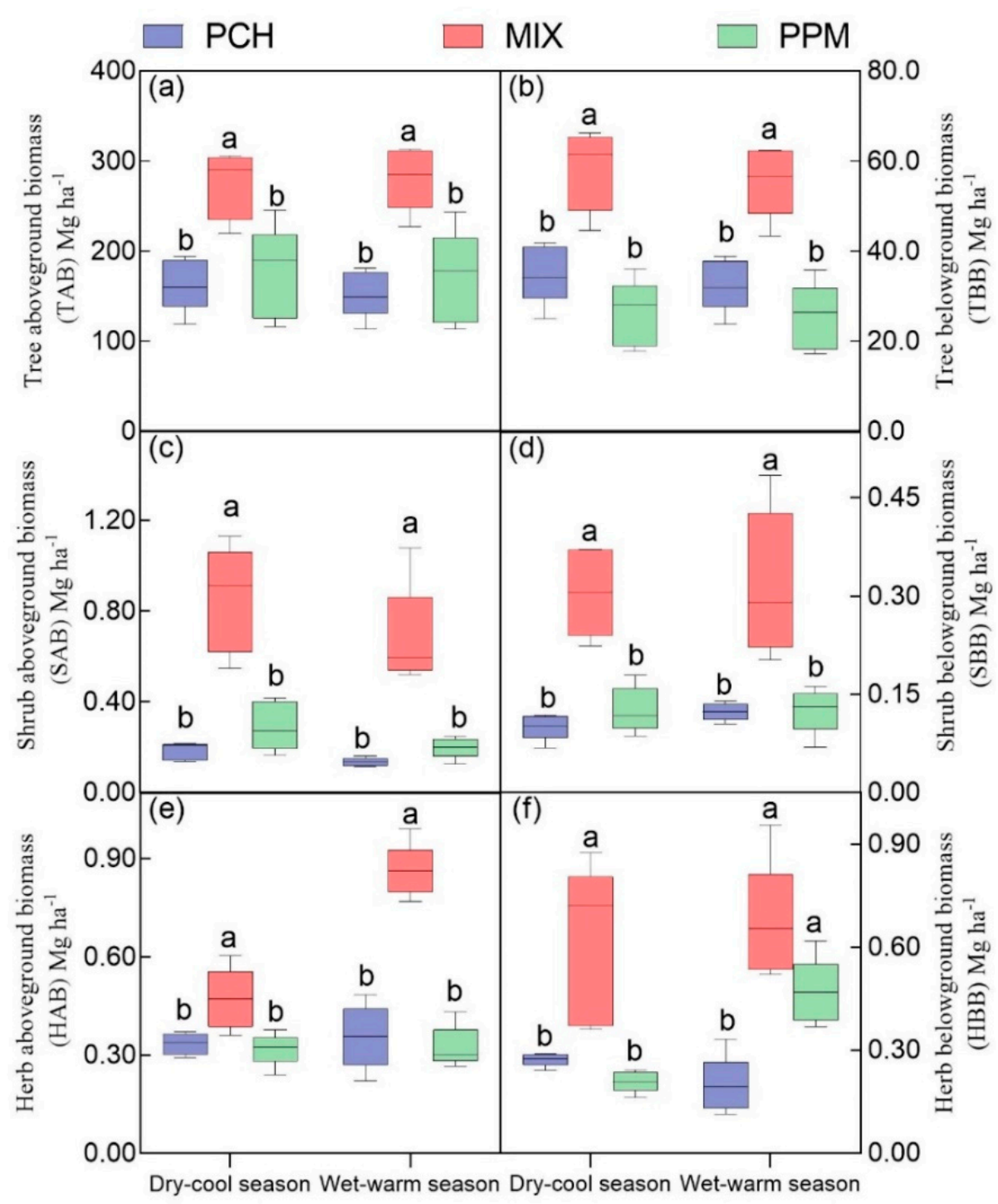

Figure 1. Biomass of trees $(\mathbf{a}, \mathbf{b})$, shrubs $(\mathbf{c}, \mathbf{d})$ and herbs $(\mathbf{e}, \mathbf{f})$ in three plantations in different seasons. Different letters above the bars denote significant differences at $p<0.05$ level by LSD (least significant difference) multiple comparisons among stand types $(n=5)$. 


\subsection{Litter Production and Quality}

Stand type, the interaction between stand type, and season significantly influenced litter production at our study sites (Table 2). The MIX had significantly higher litter production than PCH and PPM in both seasons. $\mathrm{OC}_{\text {litter }}$ and $\mathrm{CN}_{\text {litter }}$ were significantly affected by both stand type and season with higher value in the wet-warm season than in the dry-cool season in all plantations. An opposite trend was observed in $\mathrm{TN}_{\text {litter. }} \mathrm{TP}_{\text {litter }}$ was significantly affected by stand type, season, and their interaction with MIX had significantly lower concentration than PCH and PPM in the dry-cool season. $\mathrm{TK}_{\text {litter }}$ was significantly affected by stand type with MIX had significantly higher concentration than PCH and PPM in the wet-warm season. These results partially supported our first hypothesis that tree species mixture increased litter production, although the increases of litter quality in mixed plantations were not significant.

\subsection{Soil Physical and Chemical Properties}

In the dry-cool season, the mixed plantations had the highest soil bulk density (BD) and soil water content (WC), and the lowest soil temperature and medium $\mathrm{pH}$ compared to the pure plantations (Table 3). In the wet-warm season, MIX had the medium BD, WC and soil temperature, and the highest $\mathrm{pH}$ compared to PPM and PCH.

The PPM plantations had the highest SOC, TN, TP, SOC-to-TN ratio, $\mathrm{NH}_{4}{ }^{+}-\mathrm{N}$ and $\mathrm{CEC}$, while MIX had the highest AP, TK and AK, and $\mathrm{PCH}$ had the highest $\mathrm{NO}_{3}{ }^{-}-\mathrm{N}$ and $\mathrm{AN}$ in the dry-cool season (Table 3). On the other hand, the PCH had the highest SOC, TN and AP, while MIX had the highest TP, TK, $\mathrm{AK}, \mathrm{NO}_{3}{ }^{-}-\mathrm{N}$ and $\mathrm{AN}$, and PPM had the highest SOC-to-TN ratio, $\mathrm{NO}_{3}{ }^{-}-\mathrm{N}$, and $\mathrm{CEC}$ in the wet-warm season.

Two-way ANOVAs indicated that season significantly affected all the tested soil variables (Table 3). In addition, the stand type influenced nearly all soil variables except $\mathrm{BD}, \mathrm{TN}, \mathrm{NH}_{4}{ }^{+}-\mathrm{N}$ and $\mathrm{AN}$. Interactions between stand type and season significantly influenced $\mathrm{WC}$, temperature, $\mathrm{pH}, \mathrm{SOC}, \mathrm{TN}$, $\mathrm{TP}, \mathrm{AP}, \mathrm{AK}, \mathrm{NO}_{3}{ }^{-}-\mathrm{N}$ and $\mathrm{CEC}$. 
Table 2. The quantity and quality of litter in pure Castanopsis hystrix (PCH) plantation, pure Pinus massoniana (PPM) plantation, and mixed C. hystrix and P. massoniana (MIX) plantation (mean \pm standard error; $n=5$ ).

\begin{tabular}{|c|c|c|c|c|c|c|c|c|c|c|c|c|}
\hline \multirow{2}{*}{ Factors } & \multicolumn{3}{|c|}{ Dry-Cool Season } & \multicolumn{3}{|c|}{ Wet-Warm Season } & \multicolumn{2}{|c|}{ Stand Type } & \multicolumn{2}{|c|}{ Season } & \multicolumn{2}{|c|}{ Stand Type $\times$ Season } \\
\hline & PCH & MIX & PPM & $\mathrm{PCH}$ & MIX & PPM & $F$ & $p$ & $F$ & $p$ & $F$ & $p$ \\
\hline LP & $6.68 \pm 0.19^{b}$ & $8.36 \pm 0.69^{a}$ & $4.84 \pm 0.19^{c}$ & $5.53 \pm 0.43^{b}$ & $9.21 \pm 0.40^{\mathrm{a}}$ & $6.16 \pm 0.23^{b}$ & 37.52 & $<0.001$ & 0.93 & 0.343 & 5.27 & 0.013 \\
\hline $\mathrm{OC}_{\text {litter }}$ & $190.64 \pm 10.63^{b}$ & $248.59 \pm 18.48^{a}$ & $255.05 \pm 18.00^{a}$ & $277.57 \pm 18.85^{b}$ & $274.3 \pm 11.42^{b}$ & $321.75 \pm 5.44^{a}$ & 6.83 & 0.004 & 24.86 & $<0.001$ & 2.26 & 0.127 \\
\hline $\mathrm{TN}_{\text {litter }}$ & $17.38 \pm 0.78^{\mathrm{a}}$ & $13.53 \pm 1.06^{\mathrm{b}}$ & $14.96 \pm 0.62^{\mathrm{ab}}$ & $12.95 \pm 0.59^{\mathrm{a}}$ & $13.57 \pm 0.90^{\mathrm{a}}$ & $11.89 \pm 0.50^{a}$ & 3.21 & 0.058 & 15.79 & 0.001 & 4.45 & 0.023 \\
\hline $\mathrm{CN}_{\text {litter }}$ & $11.12 \pm 0.95^{b}$ & $18.50 \pm 0.81^{\mathrm{a}}$ & $17.33 \pm 1.81^{\mathrm{a}}$ & $21.82 \pm 2.23^{b}$ & $20.56 \pm 1.56^{b}$ & $27.22 \pm 0.96^{\mathrm{a}}$ & 7.67 & 0.003 & 38.90 & $<0.001$ & 5.18 & 0.013 \\
\hline $\mathrm{TP}_{\text {litter }}$ & $1.34 \pm 0.08^{a}$ & $0.50 \pm 0.07^{b}$ & $1.16 \pm 0.05^{\mathrm{a}}$ & $1.19 \pm 0.15^{\mathrm{a}}$ & $1.38 \pm 0.15^{\mathrm{a}}$ & $1.31 \pm 0.05^{\mathrm{a}}$ & 6.67 & 0.005 & 12.81 & 0.002 & 14.17 & $<0.001$ \\
\hline $\mathrm{TK}_{\text {litter }}$ & $1.16 \pm 0.16^{\mathrm{a}}$ & $1.52 \pm 0.10^{\mathrm{a}}$ & $0.82 \pm 0.09^{b}$ & $1.07 \pm 0.02^{b}$ & $1.49 \pm 0.13^{\mathrm{a}}$ & $0.88 \pm 0.07^{c}$ & 20.84 & $<0.001$ & 0.07 & 0.796 & 0.29 & 0.751 \\
\hline
\end{tabular}

Different superscripts indicate significant differences among stand types in each season $(p<0.05)$. LP $\left(\mathrm{Mg} \mathrm{ha}^{-1}\right)$, litter production; $\mathrm{OC}_{\text {litter }}\left(\mathrm{g} \mathrm{kg}^{-1}\right)$, litter organic carbon; $\mathrm{TN}_{\mathrm{litter}}\left(\mathrm{g} \mathrm{kg}^{-1}\right)$, litter total nitrogen; $\mathrm{CN}_{\text {litter }}, \mathrm{C} / \mathrm{N}$ ratio of litter; $\mathrm{TP}_{\text {litter }}\left(\mathrm{g} \mathrm{kg}^{-1}\right)$, litter total phosphorus; $\mathrm{TK}_{\text {litter }}\left(\mathrm{g} \mathrm{kg}^{-1}\right)$, litter total potassium.

Table 3. Soil physical and chemical properties (0-10 cm soil depth) in pure Castanopsis hystrix (PCH) plantation, pure Pinus massoniana (PPM) plantation, and mixed C. hystrix and P. massoniana (MIX) plantation (mean \pm standard error; $n=5$ ).

\begin{tabular}{|c|c|c|c|c|c|c|c|c|c|c|c|c|}
\hline \multirow{2}{*}{ Factors } & \multicolumn{3}{|c|}{ Dry-Cool Season } & \multicolumn{3}{|c|}{ Wet-Warm Season } & \multicolumn{2}{|c|}{ Stand Type } & \multicolumn{2}{|c|}{ Season } & \multicolumn{2}{|c|}{ Stand Type $\times$ Season } \\
\hline & PCH & Mixed & PPM & PCH & Mixed & PPM & $F$ & $p$ & $F$ & $p$ & $F$ & $p$ \\
\hline $\mathrm{BD}$ & $1.09 \pm 0.03^{b}$ & $1.25 \pm 0.04^{\mathrm{a}}$ & $1.19 \pm 0.02^{\mathrm{a}}$ & $1.03 \pm 0.01^{\mathrm{a}}$ & $1.03 \pm 0.03^{\mathrm{a}}$ & $1.04 \pm 0.05^{\mathrm{a}}$ & 3.11 & 0.063 & 30.44 & $<0.001$ & 2.97 & 0.070 \\
\hline WC & $39.66 \pm 1.36^{b}$ & $43.59 \pm 0.61^{a}$ & $40.17 \pm 1.58^{a b}$ & $40.53 \pm 1.07^{c}$ & $44.40 \pm 0.84^{b}$ & $50.48 \pm 1.41^{\mathrm{a}}$ & 10.35 & 0.001 & 16.81 & $<0.001$ & 10.48 & 0.001 \\
\hline Tem. & $16.82 \pm 0.21^{a}$ & $15.50 \pm 0.09^{c}$ & $16.17 \pm 0.05^{b}$ & $26.28 \pm 0.43^{a}$ & $25.98 \pm 0.22^{a}$ & $25.41 \pm 0.08^{a}$ & 8.21 & 0.002 & 2833.34 & $<0.001$ & 4.31 & 0.025 \\
\hline $\mathrm{pH}$ & $4.32 \pm 0.02^{\mathrm{a}}$ & $4.19 \pm 0.03^{b}$ & $4.04 \pm 0.05^{c}$ & $4.02 \pm 0.02^{b}$ & $4.21 \pm 0.03^{\mathrm{a}}$ & $3.90 \pm 0.09^{b}$ & 14.40 & $<0.001$ & 13.70 & 0.001 & 6.23 & 0.007 \\
\hline SOC & $37.42 \pm 1.08^{b}$ & $40.82 \pm 0.22^{b}$ & $56.98 \pm 1.89^{a}$ & $53.31 \pm 1.94^{a}$ & $48.39 \pm 2.00^{a}$ & $50.83 \pm 0.54^{a}$ & 24.60 & $<0.001$ & 23.69 & $<0.001$ & 28.64 & $<0.001$ \\
\hline $\mathrm{TN}$ & $1.63 \pm 0.05^{\mathrm{b}}$ & $1.60 \pm 0.06^{\mathrm{b}}$ & $2.16 \pm 0.22^{\mathrm{a}}$ & $2.48 \pm 0.11^{\mathrm{a}}$ & $2.13 \pm 0.13^{a}$ & $2.17 \pm 0.14^{\mathrm{a}}$ & 2.48 & 0.105 & 44.08 & $<0.001$ & 4.80 & 0.018 \\
\hline $\mathrm{SOC} / \mathrm{TN}$ & $22.98 \pm 0.59^{b}$ & $25.67 \pm 1.03^{b}$ & $29.49 \pm 1.59^{a}$ & $21.67 \pm 1.33^{a}$ & $23.04 \pm 1.62^{a}$ & $23.90 \pm 2.02^{a}$ & 4.57 & 0.021 & 7.22 & 0.013 & 1.14 & 0.338 \\
\hline $\mathrm{TP}$ & $0.31 \pm 0.04^{c}$ & $0.42 \pm 0.02^{b}$ & $0.60 \pm 0.04^{\mathrm{a}}$ & $0.52 \pm 0.06^{b}$ & $0.78 \pm 0.04^{\mathrm{a}}$ & $0.54 \pm 0.04^{b}$ & 21.86 & $<0.001$ & 28.89 & $<0.001$ & 17.95 & $<0.001$ \\
\hline $\mathrm{AP}$ & $9.19 \pm 0.58^{b}$ & $12.52 \pm 0.69^{a}$ & $10.02 \pm 0.30^{b}$ & $13.30 \pm 0.40^{a}$ & $13.15 \pm 0.57^{a}$ & $9.98 \pm 0.27^{b}$ & 16.70 & $<0.001$ & 15.25 & 0.001 & 10.29 & 0.001 \\
\hline TK & $4.14 \pm 0.15^{b}$ & $5.45 \pm 0.49^{\mathrm{a}}$ & $2.42 \pm 0.16^{c}$ & $5.40 \pm 0.50^{\mathrm{a}}$ & $6.94 \pm 0.82^{\mathrm{a}}$ & $3.38 \pm 0.13^{b}$ & 32.26 & $<0.001$ & 10.34 & 0.004 & 0.39 & 0.680 \\
\hline AK & $29.90 \pm 1.49^{b}$ & $46.29 \pm 0.96^{\mathrm{a}}$ & $28.46 \pm 1.08^{b}$ & $47.19 \pm 2.28^{\mathrm{a}}$ & $52.79 \pm 3.65^{\mathrm{a}}$ & $28.37 \pm 1.44^{b}$ & 53.75 & $<0.001$ & 22.57 & $<0.001$ & 9.27 & 0.001 \\
\hline $\mathrm{NO}_{3}{ }^{-}-\mathrm{N}$ & $3.55 \pm 0.24^{a}$ & $1.85 \pm 0.04^{c}$ & $2.86 \pm 0.22^{b}$ & $4.06 \pm 0.19^{c}$ & $5.30 \pm 0.09^{b}$ & $5.79 \pm 0.09^{a}$ & 10.96 & $<0.001$ & 291.06 & $<0.001$ & 45.47 & $<0.001$ \\
\hline $\mathrm{NH}_{4}{ }^{+}-\mathrm{N}$ & $21.29 \pm 1.01^{\mathrm{a}}$ & $23.34 \pm 1.13^{a}$ & $24.47 \pm 1.37^{\mathrm{a}}$ & $42.24 \pm 1.62^{a}$ & $43.50 \pm 1.66^{\mathrm{a}}$ & $38.83 \pm 2.47^{a}$ & 0.75 & 0.482 & 196.16 & $<0.001$ & 2.47 & 0.105 \\
\hline AN & $27.34 \pm 1.57^{\mathrm{a}}$ & $25.19 \pm 1.14^{a}$ & $24.85 \pm 0.90^{\mathrm{a}}$ & $46.3 \pm 1.55^{\mathrm{a}}$ & $48.8 \pm 1.69^{a}$ & $44.62 \pm 2.46^{\mathrm{a}}$ & 1.20 & 0.319 & 245.55 & $<0.001$ & 1.17 & 0.328 \\
\hline CEC & $45.53 \pm 3.27^{c}$ & $57.58 \pm 4.11^{b}$ & $82.33 \pm 1.94$ a & $55.43 \pm 2.02^{\mathrm{a}}$ & $54.46 \pm 1.19^{a}$ & $62.24 \pm 2.91^{a}$ & 45.14 & $<0.001$ & 12.16 & 0.002 & 21.68 & $<0.001$ \\
\hline
\end{tabular}

$\left(\mathrm{g} \mathrm{kg}^{-1}\right)$ soil orsanic carcon; TN $\left(\mathrm{g} \mathrm{kg}^{-1}\right)$ total nitrogen; TP $\left(\mathrm{g} \mathrm{kg}^{-1}\right)$ total phosphorus; $\mathrm{AP}\left(\mathrm{mg} \mathrm{kg}^{-1}\right)$ cm $\left.{ }^{-1}\right)$, bulk density; WC $(\%)$, soil water content; Tem. $\left({ }^{\circ} \mathrm{C}\right)$, temperature; SOC

potassium; $\mathrm{NO}_{3}{ }^{-}-\mathrm{N}\left(\mathrm{mg} \mathrm{kg}^{-1}\right)$, nitrate nitrogen; $\mathrm{NH}_{4}{ }^{+}-\mathrm{N}\left(\mathrm{mg} \mathrm{kg}^{-1}\right)$, ammonium nitrogen; $\mathrm{AN}\left(\mathrm{mg} \mathrm{kg}^{-1}\right)$, Available nitrogen; $\mathrm{CEC}\left(\mathrm{cmol}+\mathrm{kg}^{-1}\right)$, cation exchange capacity. 


\subsection{Soil Microbial Biomass and Community Structure}

Two-way ANOVAs indicated that MBC, MBN, MBC-to-SOC and MBN-to-TN were significantly affected by stand type, and MBN was also significantly affected by season and interaction between stand type and season (Table S2).

In the dry-cool season, MBC was significantly higher in MIX than in PCH and PPM (Figure 2a). In the wet-warm season, MBC was significantly higher in MIX than in PPM, and MBN was significantly higher in MIX than in PCH and PPM (Figure 2b). The coniferous-broadleaf mixed stand had the highest MBC-to-SOC and MBN-to-TN ratio in both seasons (Figure 2c,d). The differences of the MBC-to-SOC and MBN-to-TN ratio between the mixed stand and the corresponding pure stands reached a significant level in the wet season. Non-additive effects (NAE) of species mixing on MBC, MBN, MBC-to-SOC, and MBN-to-TN ratio were recorded. Synergistic effects on MBC and MBC-to-SOC ratio in the dry-cool season (Figure 3a), and on MBC, MBN, MBC-to-SOC, and MBN-to-TN ratio in the wet-warm season (Figure $3 b$ ) were significant.

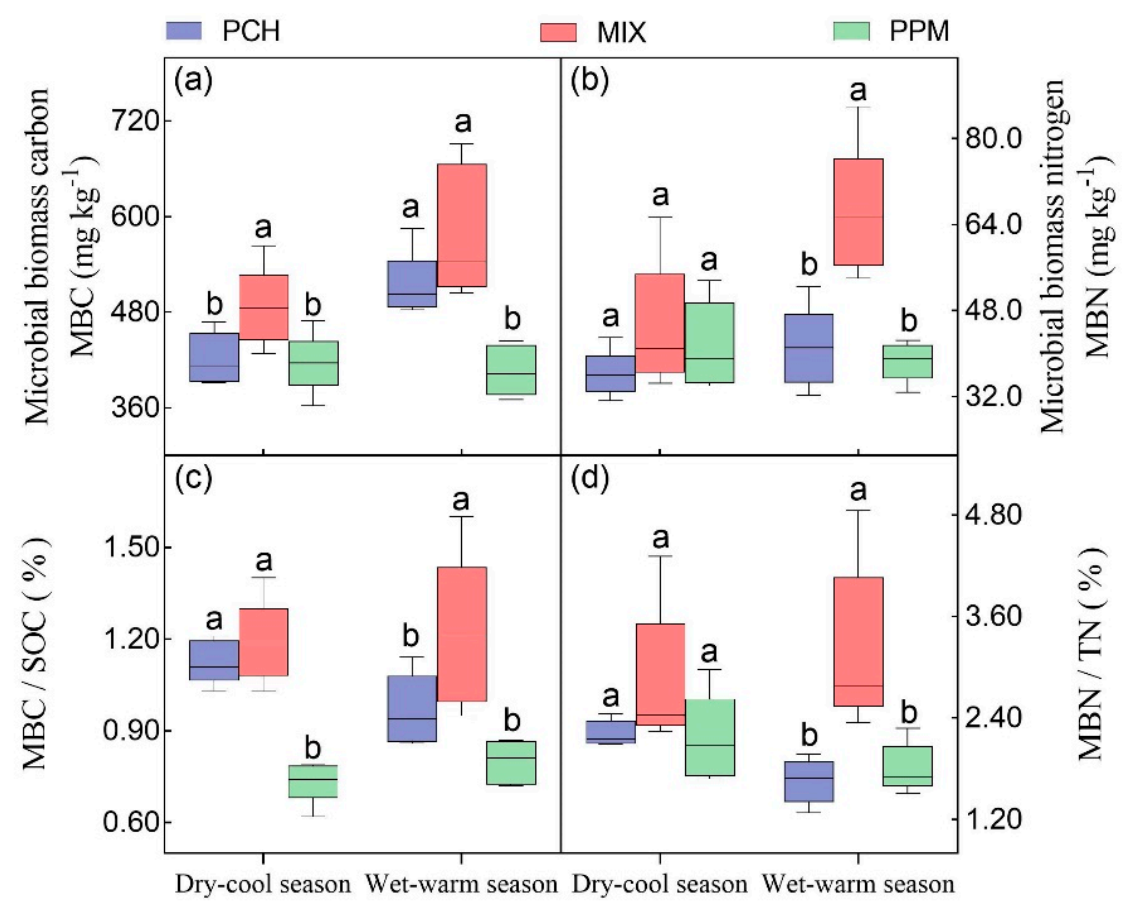

Figure 2. Soil microbial biomass in three plantations in different seasons ((a-d) refer to MBC, MBN, MBC-to-SOC and MBN-to-TN). Different letters above the bars denote significant differences at $p<0.05$ level by LSD multiple comparisons among stand types $(n=5)$.

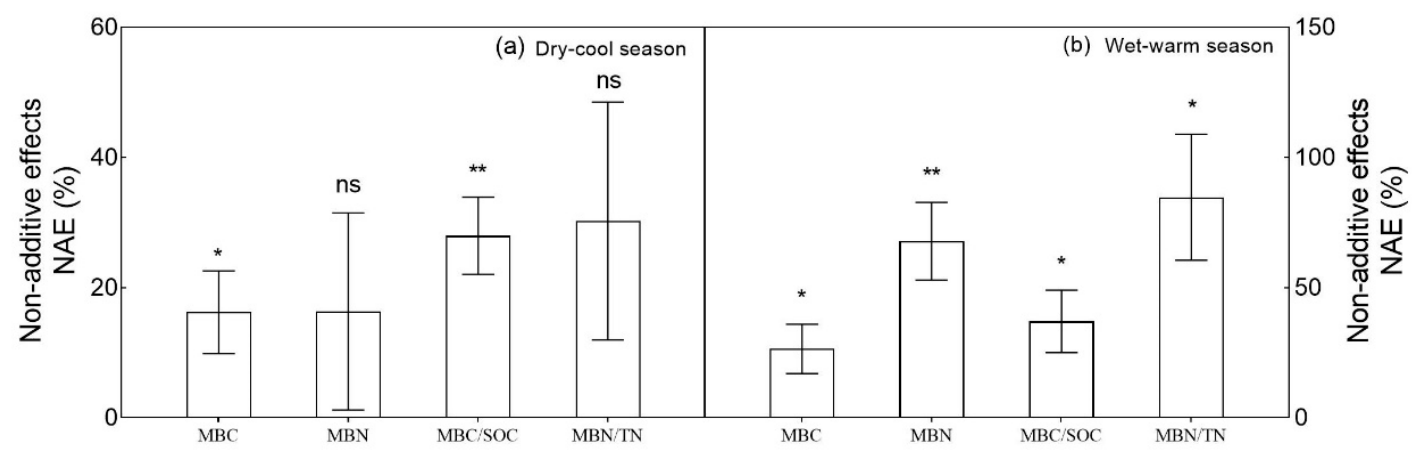

Figure 3. Not-additive effects of mixed plantation on soil microbial biomass in the dry-cool season (a) and wet-warm season (b). 
In the dry-cool season, total PLFAs, AMF PLFAs, actinobacteria PLFAs, bacteria PLFAs, fungi PLFAs, GP bacteria PLFAs, and GP-to-GN PLFAs ratio were smaller in MIX than those in PPM and $\mathrm{PCH}$. On the other hand, in the wet-warm season, these PLFAs were smaller in PPM than those in PCH and MIX (Table 4). Specifically, the ratios of bacteria-to-fungi PLFA and GP-to-GN PLFA were significantly higher in MIX than those in PPM and PCH in the wet-warm season. These results indicated that the response of the soil microbial community structure to tree species mixture varied in different seasons. Two-way ANOVAs showed that both stand type and season significantly affected all the tested microbial variables, while the interaction between stand type and season significantly influenced total PLFAs, bacteria PLFAs, GP bacteria PLFAs, Acti PLFAs, bacteria-to-fungi PLFA, and GP-to-GN PLFA (Table 4).

Across plantations and seasons, bacteria PLFAs were the most abundant, followed by fungi and actinobacteria PLFAs (Figure 4 and Table S3). It was worth noting that the relative abundance of GN bacteria PLFAs was significantly higher in MIX than in other plantations in the dry-cool season (Figure 4). Furthermore, the relative abundance of GP bacteria PLFAs was significantly higher, and that of fungi PLFAs was significantly lower in MIX than in other plantations in the wet-warm season.

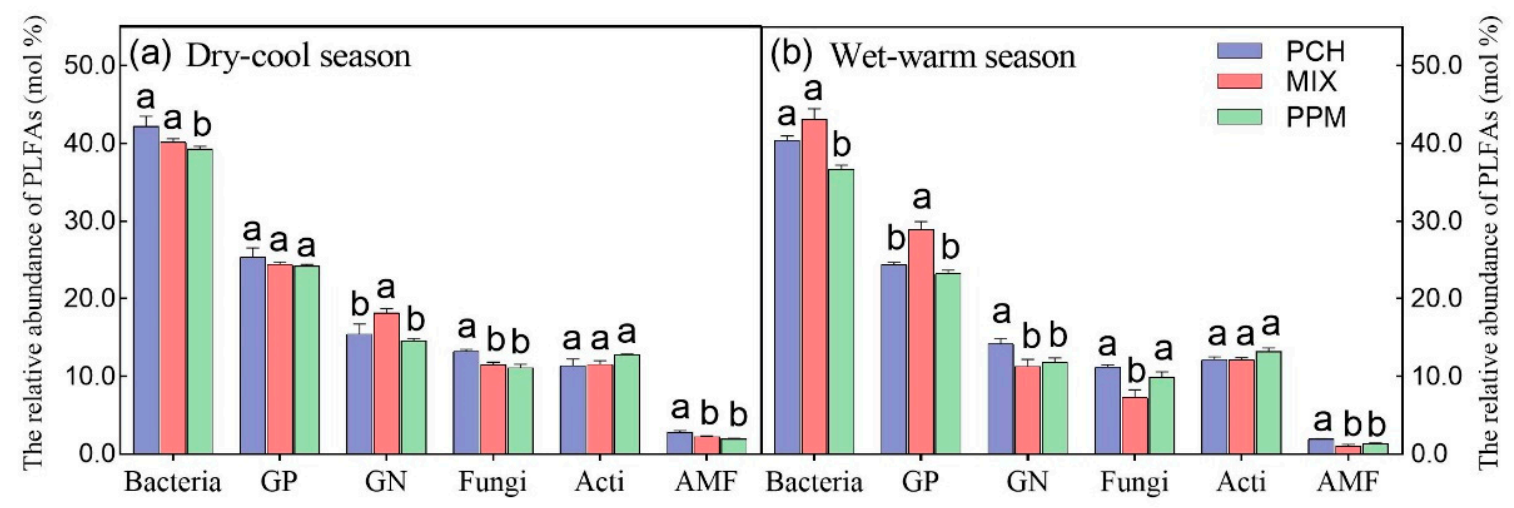

Figure 4. The relative abundance of PLFAs ( $\mathrm{mol} \%$ ) in three plantations in the dry-cool season (a) and wet-warm season $(\mathbf{b})$. Different letters above the bars denote significant differences at $p<0.05$ level by LSD multiple comparisons among stand types $(n=5)$. 
Table 4. Soil microbial community PLFAs content and structure (0-10 cm soil depth) in pure Castanopsis hystrix (PCH) plantation, pure Pinus massoniana (PPM) plantation, and mixed C. hystrix and P. massoniana (MIX) plantation (mean \pm standard error; $n=5$ ).

\begin{tabular}{|c|c|c|c|c|c|c|c|c|c|c|c|c|}
\hline \multirow{2}{*}{ Factors } & \multicolumn{3}{|c|}{ Dry-Cool Season } & \multicolumn{3}{|c|}{ Wet-Warm Season } & \multicolumn{2}{|c|}{ Stand Type } & \multicolumn{2}{|c|}{ Season } & \multicolumn{2}{|c|}{ Stand Type $\times$ Season } \\
\hline & PCH & MIX & PPM & PCH & MIX & PPM & $F$ & $p$ & $F$ & $p$ & $F$ & $p$ \\
\hline TPLFAs & $37.67 \pm 2.71^{a}$ & $32.55 \pm 1.24^{\mathrm{a}}$ & $37.96 \pm 1.28^{a}$ & $43.73 \pm 2.08^{a}$ & $40.01 \pm 0.7^{\mathrm{a}}$ & $34.78 \pm 1.11^{b}$ & 4.64 & 0.020 & 6.46 & 0.018 & 6.07 & 0.007 \\
\hline B & $15.79 \pm 0.81^{a}$ & $13.06 \pm 0.43^{b}$ & $14.90 \pm 0.51^{a b}$ & $17.64 \pm 0.72^{a}$ & $17.23 \pm 0.42^{\mathrm{a}}$ & $12.76 \pm 0.41^{b}$ & 12.74 & $<0.001$ & 7.68 & 0.011 & 15.56 & $<0.001$ \\
\hline GP & $9.45 \pm 0.43^{\mathrm{a}}$ & $7.94 \pm 0.29 \mathrm{~b}$ & $9.18 \pm 0.31^{\mathrm{a}}$ & $10.66 \pm 0.51^{a}$ & $11.55 \pm 0.31^{\mathrm{a}}$ & $8.10 \pm 0.31^{b}$ & 8.17 & 0.002 & 17.09 & $<0.001$ & 20.30 & $<0.001$ \\
\hline GN & $5.91 \pm 0.76^{\mathrm{a}}$ & $5.90 \pm 0.16^{\mathrm{a}}$ & $5.53 \pm 0.222^{a}$ & $6.19 \pm 0.25^{a}$ & $4.55 \pm 0.37^{b}$ & $4.11 \pm 0.20^{b}$ & 5.26 & 0.013 & 7.02 & 0.014 & 3.13 & 0.062 \\
\hline $\mathrm{F}$ & $4.98 \pm 0.34^{\mathrm{a}}$ & $3.75 \pm 0.22^{b}$ & $4.24 \pm 0.28^{\mathrm{ab}}$ & $4.92 \pm 0.35^{\mathrm{a}}$ & $2.96 \pm 0.43^{b}$ & $3.45 \pm 0.21^{b}$ & 13.56 & $<0.001$ & 4.48 & 0.045 & 0.91 & 0.416 \\
\hline AMF & $1.04 \pm 0.03^{a}$ & $0.75 \pm 0.03^{b}$ & $0.75 \pm 0.04^{b}$ & $0.85 \pm 0.07^{\mathrm{a}}$ & $0.44 \pm 0.08^{b}$ & $0.48 \pm 0.03^{b}$ & 28.22 & $<0.001$ & 34.83 & $<0.001$ & 0.56 & 0.577 \\
\hline Acti & $4.26 \pm 0.37^{a b}$ & $3.77 \pm 0.21^{b}$ & $4.86 \pm 0.20^{\mathrm{a}}$ & $5.31 \pm 0.19^{a}$ & $4.87 \pm 0.12^{b}$ & $4.58 \pm 0.10^{b}$ & 2.73 & 0.085 & 12.36 & 0.002 & 6.50 & 0.006 \\
\hline $\mathrm{B} / \mathrm{F}$ & $3.19 \pm 0.11^{\mathrm{a}}$ & $3.51 \pm 0.13^{a}$ & $3.56 \pm 0.17^{a}$ & $3.62 \pm 0.14^{b}$ & $6.35 \pm 0.94 \mathrm{a}$ & $3.77 \pm 0.33^{b}$ & 7.50 & 0.003 & 11.31 & 0.003 & 5.98 & 0.008 \\
\hline GP/GN & $1.74 \pm 0.29^{b}$ & $1.35 \pm 0.03^{b}$ & $1.66 \pm 0.04^{\mathrm{a}}$ & $1.73 \pm 0.08^{b}$ & $2.63 \pm 0.28^{a}$ & $1.98 \pm 0.11^{b}$ & 1.07 & 0.359 & 13.76 & 0.001 & 7.33 & 0.003 \\
\hline
\end{tabular}

soil) arbuscular mycorrhizal fungi PLFAs; B/F, bacteria-to-fungi PLFA ratio; GP/GN, GP-to-GN ratio. 


\subsection{Soil Microbial Functions}

Soil enzyme activity was lower in the pure coniferous plantation (PPM) than in the pure broadleaf plantation in both seasons (Figure 5 and Table S4). The mixture of tree species significantly increased APH and NAG activity in the dry-cool season. Furthermore, mixed tree species significantly increased urease and $\mathrm{PO}$ activity but significantly decreased APH activity in the wet-warm season (Figure $5 \mathrm{~d}, \mathrm{f}, \mathrm{g}$ ). Carbon source utilization ability of the soil microbial community, indicated by average well color development (AWCD), was significantly higher in MIX than in PCH and PPM after $144 \mathrm{~h}$ of incubation (Figure 6).

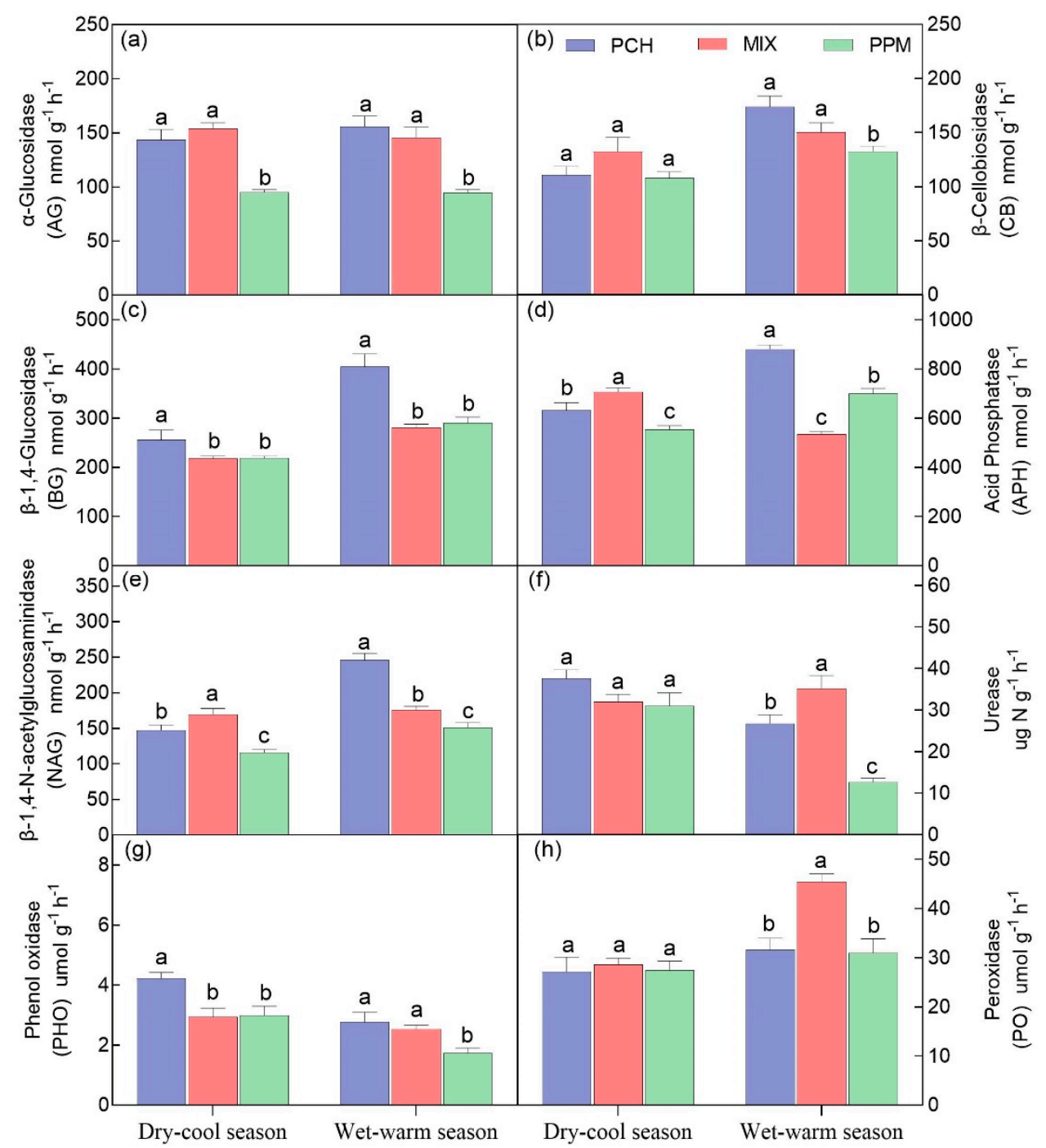

Figure 5. Soil extracellular enzyme activities ((a-f) refer to hydrolases, $(\mathbf{g}, \mathbf{h})$ refer to oxidases) in three plantations in different seasons. Error bars are standard error. Different letters above the bars denote significant differences at $p<0.05$ level by LSD multiple comparisons among stand types $(n=5)$. 


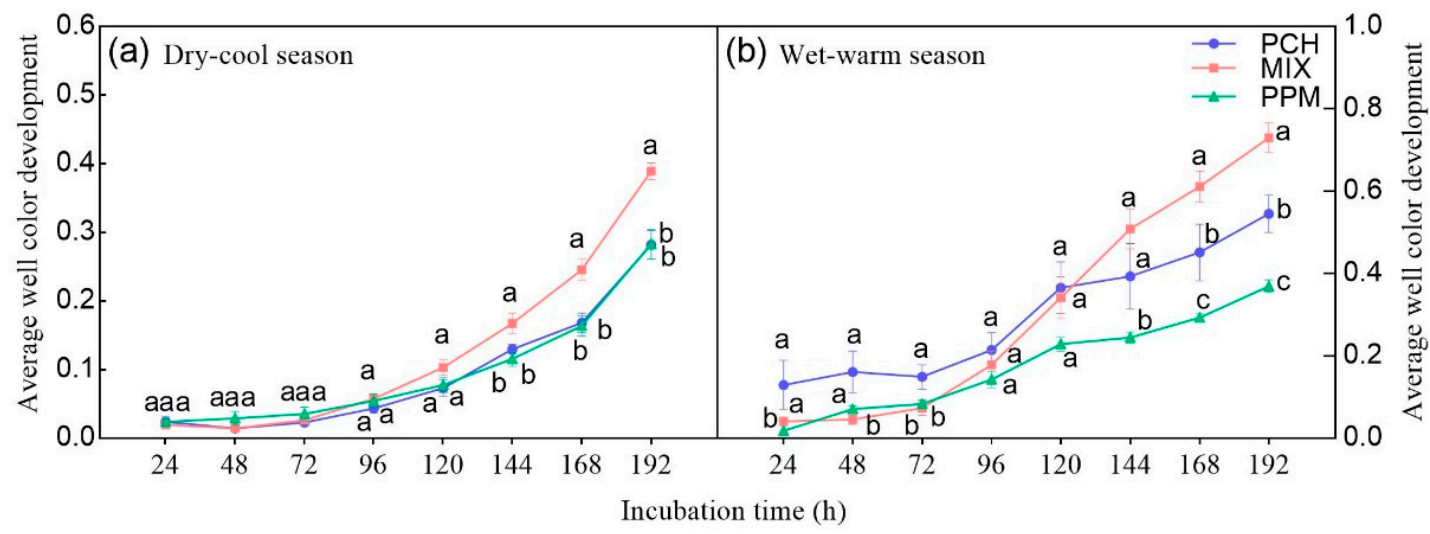

Figure 6. Soil microbial activity represented by average well color development (AWCD) in three plantations in the dry-cool season (a) and wet-warm season (b). Different letters above the bars denote significant differences at $p<0.05$ level by LSD multiple comparisons among stand types $(n=5)$.

\subsection{Relationship between Biotic and Abiotic Factors and Soil Microbial Composition}

The first two RDA axes explained $64.60 \%$ of the variation in soil microbial composition in the dry-cool season $(F=2.0, p=0.044$, Figure $7 \mathrm{a})$ and $65.87 \%$ of the variation in the wet-warm seasons $(F=2.3, p=0.036$, Figure $7 \mathrm{c})$. Nine biotic and abiotic factors, including SOC, TBB, TN, CEC, $\mathrm{pH}$, $\mathrm{TK}, \mathrm{LP}, \mathrm{TP}$, and $\mathrm{TK}_{\text {litter, }}$, were significantly related to the soil microbial composition in the dry-cool season, in which SOC and TBB were the major correlates of changes in soil microbial composition (Table S5). A total of 11 biotic and abiotic factors, including $\mathrm{NO}_{3}{ }^{-} \mathrm{N}, \mathrm{TBB}, \mathrm{pH}, \mathrm{TK}_{\text {litter }}, \mathrm{HBB}, \mathrm{AP}, \mathrm{AK}$, $\mathrm{TP}, \mathrm{SAB}, \mathrm{LP}$, and SWC were significantly related to the soil microbial composition in the wet-warm season, in which $\mathrm{NO}_{3}{ }^{-}-\mathrm{N}, \mathrm{TBB}, \mathrm{pH}$ and $\mathrm{TK}_{\text {litter }}$ were the major correlates of changes in soil microbial composition (Table S5). Specifically, the Gram-positive bacteria, a15:0, a17:0, i17:0, i14:0, i15:0 and i16:0, were positively related to TBB, $\mathrm{pH}$, and $\mathrm{TK}_{\text {litter }}$ in MIX during the wet-warm season (Figure 7c).

\subsection{Relationship between Soil Microbial Structure and Functions}

Soil enzyme activity and soil microbial carbon source utilization ability are both important soil microbial functions. The first two RDA axes explained $49.48 \%$ of the variation in soil enzyme activity and carbon utilization ability in the dry-cool season $(F=2.4, p=0.006$, Figure $7 \mathrm{~b})$ and $68.91 \%$ of the variation in the wet-warm season $(F=6.4, p=0.002$, Figure $7 \mathrm{~d})$. AMF and GP were significantly correlated with soil microbial functions in the dry-cool season (Table S6). Total bacteria, GP bacteria, GN bacteria, and actinobacteria were significantly correlated with soil microbial functions in the wet-warm season, in which total bacteria, GP bacteria, and GN bacteria were the major correlates of changes of soil enzyme activity (Table S6). 

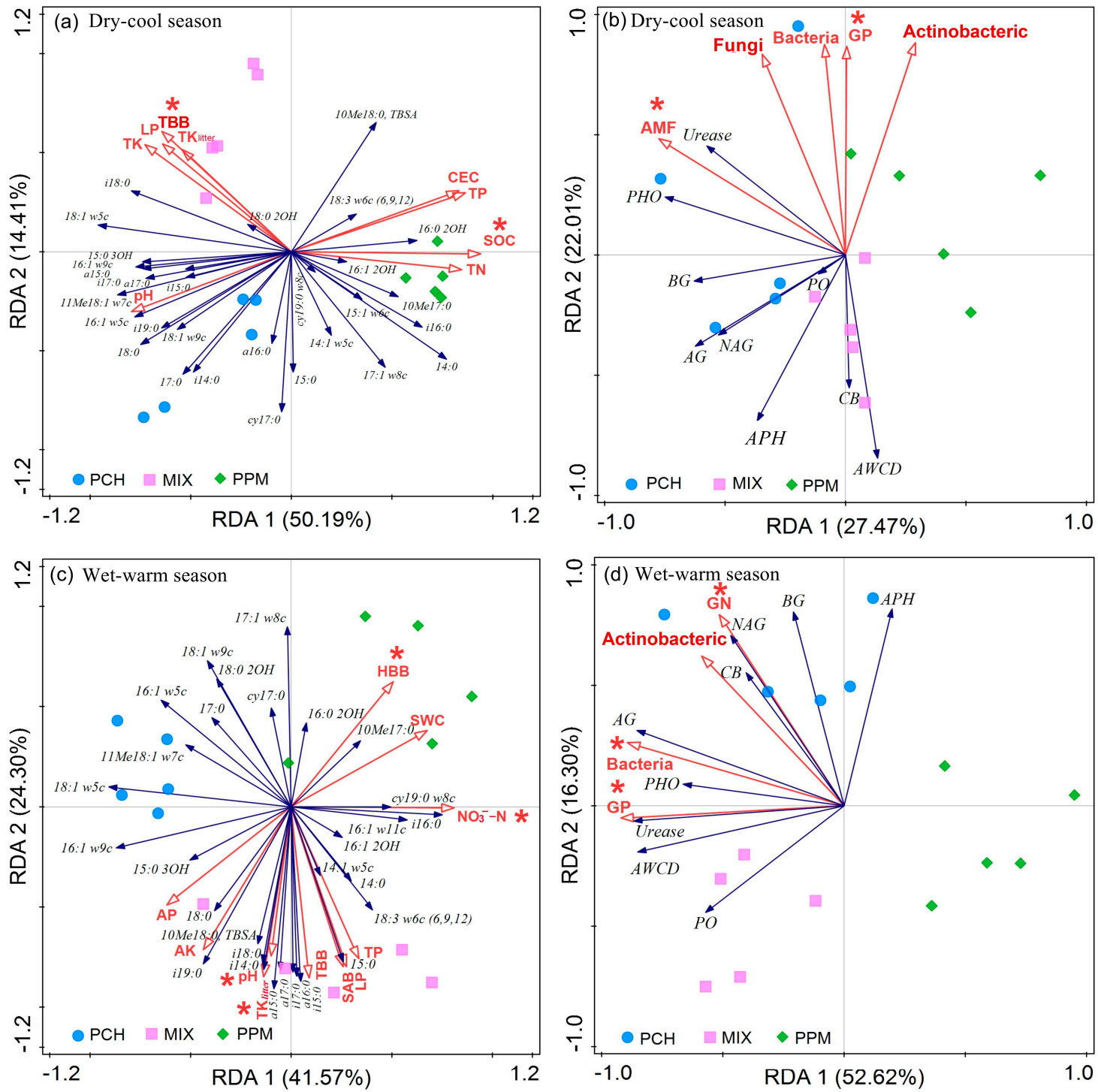

Figure 7. Redundancy analysis (RDA) ordination biplot of individual PLFAs and dominant biotic and abiotic factors in dry-cool season and wet-warm season $(\mathbf{a}, \mathbf{c})$. And RDA ordination biplot of soil microbial community structure and soil microbial functions $(\mathbf{b}, \mathbf{d}) .{ }^{*}$ Above the label represents a significant conditional effect of this factor $(p<0.05)$. SOC, soil organic carbon; TBB, tree belowground biomass; TP, soil total phosphorus; TN, soil total nitrogen; CEC, soil cation exchange capacity; TK, soil total potassium; $\mathrm{NO}_{3}{ }^{-}-\mathrm{N}$, soil nitrate nitrogen; $\mathrm{HBB}$, herb belowground biomass; $\mathrm{AP}$, soil available phosphorus; AK, soil available potassium; SAB, shrubs aboveground biomass; SWC, soil water content; LP, litter production; $\mathrm{TK}_{\text {litter }}$, litter total potassium; GP, gram-positive bacteria; GN, gram negative bacteria; AMF, arbuscular mycorrhizal fungi; AG, $\alpha$-Glucosidase; BG, $\beta$-1,4-glucosidase; $\mathrm{CB}, \beta$-Cellobiosidase; APH, acid phosphatase; NAG, $\beta$-1,4-N-acetylglucosaminidase; PHO, phenol oxidase; PO, peroxidase; AWCD, average well color development of carbon source metabolism at $192 \mathrm{~h}$ incubation.

\section{Discussion}

\subsection{Coniferous-Broadleaf Mixture Significantly Increase Stand Biomass and Litter Production}

The results of this study indicated that admixing of coniferous and broadleaf tree species significantly increased stand biomass and litter production after 34 years of afforestation in both dry-cool and wet-warm seasons (Figure 1, Table 2). This may be a consequence of a greater growth of 
C. hystrix in the mixed stands. These results confirmed previous findings conducted in our experiment site measured when the plantations were 26-year-old and 28-year-old, respectively [7,16]. A bulk of studies revealed that mixed-species management could affect tree growth, stand structure and environment $[14,52,53]$. Mixed forests can develop stratified canopies due to niche differences among different species. In the present study, trees of the faster growing broad-leaf species (C. hystrix) were taller, had a larger DBH, and thus formed an upper canopy stratum in the mixed stands (Table 1). While trees of the shorter species (P. massoniana) formed a lower stratum with lower DBH and tree height, and the reduced amount of light transmitted through the upper canopy contributed to their slower growth. The dominant tree species within the stand can absorb more sunlight and use it more efficiently for growth [54], and thus contribute to higher tree biomass and litter production in mixed stands. In addition, stratified canopies in mixed plantations can help to maintain levels of understory species richness and biomass compared with pure plantations due to relatively high light availabilities $[55,56]$. This may be why the mixed stand had higher shrub and herb biomass in our study.

Specifically, in the present study, the broad-leaf species attained greater heights and diameters in mixed stands, while masson pine had reduced diameter and height growth in mixed-species compared to mono-species stands (Table 1). The severe suppression of P. massoniana by the faster growing C. hystrix may be attributed to differences in the light requirements of the two species [7]. The growth pattern of C. hystrix and P. massoniana in mixed stands in our study (34-year-old) were differed from when they were 26-years-old, in which the growth of C. hystrix and P. massoniana in mixed stands were both greater than in the corresponding mono-species stands [7]. This suggests that effects of the tree species mixture could change over time, and long-term investigation of mixed forests is of great significance to reveal mixed effects.

\subsection{Coniferous-Broadleaf Mixture Significantly Increase Soil Microbial Biomass}

The changes of tree species and composition may significantly affect the amount of organic matter input in soil [57]. As the most active part in soil organic matter (SOM), soil microbial biomass is important in nutrient cycling and release, participating in the circulation of critical elements such as carbon and nitrogen [23]. Because of the quantity and quality of the bulk of SOM changes slowly and the changes of SOM are difficult to measure due to the spatial heterogeneity of soils, soil microbial biomass and, in particular, MBC-to-SOC and MBN-to-TN ratio have been suggested as indicators of the state and modification of SOM [58-60] and as an indicator for carbon (nitrogen) availability in soil $[61,62]$. The concentrations of SOC, TN and MBC and MBN measured in our study were affected by stand type and seasons (Table 3 and Table S2, Figure 2). In the dry cool season, although the SOC content in mixed stands did not significantly differ with that in $\mathrm{PCH}$, but significantly lower than that in PPM, the MBC concentration in mixed stands was markedly higher than that in the corresponding mono-species stands. Likewise, although the TN content in mixed stands was smaller than that in PCH and PPM stands, the MBN content in mixed stands was markedly higher than that in the corresponding mono-species stands in the wet-warn season. Previous studies found that higher soil microbial biomass correlated with higher SOC and TN content that sustain microbial metabolism [21,63]. However, in our study, the lower SOC and TN content in MIX was able to maintain a higher microbial biomass than sites where SOC was more abundant. Presumably, the quality of SOC could explain such a trend [64] and merit further investigation.

In this study, MBC-to-SOC and MBN-to-TN ratio were significantly higher in mixed stands (Figure 2), suggesting higher carbon and nitrogen availability in soil and higher soil quality for the growth of soil microorganisms by coniferous-broadleaf mixture [21]. In addition, the effects of admixing on soil microbial biomass, MBC-to-SOC, and MBN-to-TN ratio were non-additive, suggesting the interaction of $P$. massoniana and $C$. hystrix can have a synergistic effect on improving soil carbon and nitrogen availability (Figure 3). These findings are consistent with many previous studies that have determined the effects of tree species mixture on soil microbial biomass $[21,65]$. These results may be 
contributed to (1) greater amount and more diverse organic matter input via litter and rhizodeposition products in the mixture of two contrasting tree species [21]; (2) the higher use efficiency of soil organic carbon and nitrogen by microorganisms in mixed stands [66].

We also sought to determine the admixing effects on composition and abundance of soil microbial community with community-level PLFA profiles. Surprisingly, there were not significant admixing effects on PLFA content of the major microbial functional groups, such as bacteria, fungi, AMF, and actinobacteria (Table 4). However, tree species mixture significantly increased the abundance of GN bacteria in the dry-cool season, while markedly increased the abundance of GP bacteria but decreased the abundance of fungi in the wet-warn season (Figure 4). It seemed that the dominated GN bacteria in the dry-cool season and GP bacteria in the wet-warn season would correlate with the higher availability of soil organic carbon and nitrogen in mixed stands $[67,68]$. These correlations are complicated and further investigation is required to reveal the underlying mechanisms.

\subsection{Effects of Coniferous-Broadleaf Mixture on Soil Microbial Functions}

Soil microorganisms excrete soil enzymes to drive nutrient mineralization and litter decomposition [64]. Therefore, soil extracellular enzyme activities may be related to the carbon, nitrogen, and phosphorus cycling in soil $[69,70]$. In the present study, we found positive admixing effects on the activities of APH and NAG in the dry-cool season (Figure 5d,e). On the other hand, positive admixing effects on the activities of urease and peroxidase while negative admixing effects on APH was detected in the wet-warn season (Figure $5 \mathrm{~d}, \mathrm{f}, \mathrm{g}$ ). This result suggests that the mixture of C. hystrix and P. massoniana can accelerate the mineralization rates of soil organic phosphorus and nitrogen. These findings were consistent with previous study [67].

The community-level physiological profiling (CLPP) is widely used to characterize microbial communities [71-73]. The average well color development (AWCD) in the CLPP approach reflects the ability of soil microorganisms to utilize carbon sources and their metabolic activity. The higher AWCD represents the stronger metabolic activity of soil microorganisms [71]. In this present study, we detected a significantly positive admixing effect on carbon source utilization ability of the soil microbial communities in both dry-cool and wet-warn seasons after $144 \mathrm{~h}$ of incubation (Figure 6). Moreover, the RDA analysis revealed that carbon source utilization ability of the soil microbial communities were positive related with $\mathrm{APH}$ in the dry-cool season, while related with urease and peroxidase activities in the wet-warn season (Figure 7). As a whole, the higher soil microbial functions in mixed stands are likely the results of the effects of AMF and GP bacteria in the dry-cool season and the effects of bacteria, including GP and GN bacteria, the wet-warn season (Table S6).

\section{Conclusions}

In our study, we measured significantly higher tree, shrub, and herb biomass and litter production in the coniferous-broadleaf mixed plantation after 34 years of afforestation. As expected, MBC, MBN, MBC-to-SOC, and MBN-to-TN ratio were significantly higher in mixed stands, suggesting higher carbon and nitrogen availability in soil and higher soil quality for the growth of soil microorganisms in our coniferous-broadleaf mixed stand. In addition, coniferous-broadleaf mixture can increase carbon source utilization ability of soil microbial community and accelerate the mineralization rates of soil organic phosphorus and nitrogen by increasing acid phosphatase, $\beta-1,4-\mathrm{N}$-acetylglucosaminidase, and urease activities. The higher soil microbial biomass and activities are likely the result of greater amount and more diverse organic matter input via litter and rhizodeposition products, and the higher use efficiency of soil organic carbon and nitrogen by microorganisms in mixed stands. However, the correlations between soil dominated microbial functional groups and the higher availability of soil organic carbon and nitrogen, along with the quality of SOC, in mixed stands merit further investigation. Our results highlight that establishment of coniferous-broadleaf mixed forests may be a good management practice as coniferous-broadleaf mixture could accumulate higher stand 
biomass, return more litter, and increase soil microbial biomass and functions over the long term in subtropical China.

Supplementary Materials: The following are available online at http://www.mdpi.com/1999-4907/10/10/879/s1, Table S1: Effects of stand type, season and their interactions on stand biomass, Table S2: Effects of stand type, season and their interactions on soil microbial structure, Table S3: Effects of stand type, season and their interactions on relative abundance of the soil microbial community PLFAs, Table S4: Effects of stand type, season and their interactions on soil enzyme activity, Table S5: Marginal and conditional effects of biotic and abiotic factors on soil microbial composition obtained from the summary of forward selection in Redundancy analysis (RDA), Table S6: Marginal and conditional effects of soil microbial functional groups on soil enzyme activity and soil microbial carbon source utilization ability obtained from the summary of forward selection in Redundancy analysis (RDA).

Author Contributions: W.W. collected data, made experiment, analysis formal data and drafted the manuscript; Y.W. designed the work; X.Z. revised the manuscript and participated in analyzing the experiment data; H.Z., Y.Y., X.H., and X.L., Z.Q., Y.L., L.Y., H.L. participated in collecting the experiment data.

Funding: This research was funded by National Natural Science Foundation of China (31860171, 31460121, 31560201), the Guangxi Key Research and Development Program (2018AB40007), Innovation Project of Guangxi Graduate Education (YCBZ2017011), and the Guangxi Universities Science and technology (201201ZD001).

Acknowledgments: We gratefully acknowledge the supports in field sampling by the Experimental Center of Tropical Forestry, Chinese Academy of Forestry. A special acknowledgment is given to Patrick M. Finnegan for his writing suggestions.

Conflicts of Interest: The authors declare no conflicts of interest.

\section{References}

1. Zhang, X.; Liu, S.; Huang, Y.; Fu, S.; Wang, J.; Ming, A.; Li, X.; Yao, M.; Li, H. Tree species mixture inhibits soil organic carbon mineralization accompanied by decreased r-selected bacteria. Plant Soil 2018, 431, $203-216$. [CrossRef]

2. Pan, Y.; Birdsey, R.A.; Fang, J.; Houghton, R.; Kauppi, P.E.; Kurz, W.A.; Phillips, O.L.; Shvidenko, A.; Lewis, S.L.; Canadell, J.G.; et al. A large and persistent carbon sink in the world's forests. Science 2011, 333, 988-993. [CrossRef] [PubMed]

3. Chen, X.; Ju, Q.; Lin, K. Development status, issues and countermeasures of China' s plantation. World For. Res. 2014, 27, 54-59.

4. Wang, H.; Lencinas, M.V.; Ross Friedman, C.; Wang, X.; Qiu, J. Understory plant diversity assessment of Eucalyptus plantations over three vegetation types in Yunnan, China. New For. 2011, 42, 101-116. [CrossRef]

5. Sang, P.M.; Lamb, D.; Bonner, M.; Schmidt, S. Carbon sequestration and soil fertility of tropical tree plantations and secondary forest established on degraded land. Plant Soil 2013, 362, 187-200. [CrossRef]

6. Li, C.; Zhou, X.; Wen, Y.; Zhu, H.; Qin, Z.; Li, X.; You, Y.; Huang, X. Effects of high-generation ratations of Eucalyptus on undergrowth, soil fertility and enzyme activities. Guangxi Sci. 2019, 26, 176-186.

7. You, Y.; Huang, X.; Zhu, H.; Liu, S.; Liang, H.; Wen, Y.; Wang, H.; Cai, D.; Ye, D. Positive interactions between Pinus massoniana and Castanopsis hystrix species in the uneven-aged mixed plantations can produce more ecosystem carbon in subtropical China. For. Ecol. Manag. 2018, 410, 193-200. [CrossRef]

8. Huang, X.; Liu, S.; You, Y.; Wen, Y.; Wang, H.; Wang, J. Microbial community and associated enzymes activity influence soil carbon chemical composition in Eucalyptus urophylla plantation with mixing $\mathrm{N}^{2}$-fixing species in sub-tropical China. Plant Soil 2017, 414, 199-212. [CrossRef]

9. Kelty, M.J. The role of species mixtures in plantation forestry. For. Ecol. Manag. 2006, 233, 195-204. [CrossRef]

10. Bauhus, J.; Khanna, P.; Menden, N. Aboveground and belowground interactions in mixed plantations of Eucalyptus globulus and Acacia mearnsii. Can. J. For. Res. 2000, 30, 1886-1894. [CrossRef]

11. Vandermeer, J. The Ecology of Intercropping; Cambridge University Press: New York, NY, USA, 1989 ; p. 237.

12. Forrester, D.I. The spatial and temporal dynamics of species interactions in mixed-species forests: From pattern to process. For. Ecol. Manag. 2014, 312, 282-292. [CrossRef]

13. Forrester, D.I.; Bauhus, J. A review of processes behind diversity-productivity relationships in forests. Curr. For. Rep. 2016, 2, 45-61. [CrossRef]

14. Wang, H.; Liu, S.; Wang, J.; You, Y.; Yang, Y.; Shi, Z.; Huang, X.; Zheng, L.; Li, Z.; Ming, A.; et al. Mixed-species plantation with Pinus massoniana and Castanopsis hystrix accelerates $C$ loss in recalcitrant coniferous litter but slows C loss in labile broadleaf litter in southern China. For. Ecol. Manag. 2018, 422, 207-213. [CrossRef] 
15. Zhao, Z.; Jia, H.; Cai, D.; Pang, S.; Ang, N.; Liu, Y. Natural regeneration and its influencing factors of Castanopsis hystrix. J. Beijing For. Univ. 2018, 40, 76-83.

16. He, Y.; Qin, L.; Li, Z.; Liang, X.; Shao, M.; Tan, L. Carbon storage capacity of monoculture and mixed-species plantations in subtropical China. For. Ecol. Manag. 2013, 295, 193-198. [CrossRef]

17. He, Y.; Liang, X.; Qin, L.; Li, Z.; Tan, L.; Shao, M. Community structure, species diversity of Pinus massoniana and Castanopsis hystrix plantation and the nature-based forest management in the southern subtropical China. Sci. Silvae Sin. 2013, 49, 24-33.

18. Cline, L.C.; Zak, D.R. Soil microbial communities are shaped by plant-driven changes in resource availability during secondary succession. Ecology 2015, 96, 3374-3385. [CrossRef]

19. Malchair, S.; Carnol, M. Microbial biomass and $\mathrm{C}$ and $\mathrm{N}$ transformations in forest floors under European beech, Sessile oak, Norway spruce and Douglas-fir at four temperate forest sites. Soil Biol. Biochem. 2009, 41, 831-839. [CrossRef]

20. Ming, A.; Yang, Y.; Liu, S.; Wang, H.; Li, Y.; Li, H.; Nong, Y.; Cai, D.; Jia, H.; Tao, Y.; et al. Effects of near natural forest management on soil greenhouse gas flux in Pinus massoniana (Lamb.) and Cunninghamia lanceolata (Lamb.) Hook. plantations. Forests 2018, 9, 229. [CrossRef]

21. Wen, L.; Lei, P.; Xiang, W.; Yan, W.; Liu, S. Soil microbial biomass carbon and nitrogen in pure and mixed stands of Pinus massoniana and Cinnamomum camphora differing in stand age. For. Ecol. Manag. 2014, 328, 150-158. [CrossRef]

22. Van Der Heijden, M.G.A.; Bardgett, R.D.; Van Straalen, N.M. The unseen majority: Soil microbes as drivers of plant diversity and productivity in terrestrial ecosystems. Ecol. Lett. 2008, 11, 296-310. [CrossRef] [PubMed]

23. Singh, J.S.; Gupta, V.K. Soil microbial biomass: A key soil driver in management of ecosystem functioning. Sci. Total Environ. 2018, 634, 497-500. [CrossRef] [PubMed]

24. Chen, C.; Chen, H.Y.H.; Chen, X.; Huang, Z. Meta-analysis shows positive effects of plant diversity on microbial biomass and respiration. Nat. Commun. 2019, 10, 1332. [CrossRef] [PubMed]

25. Boer, W.; Folman, L.B.; Summerbell, R.C.; Boddy, L. Living in a fungal world: Impact of fungi on soil bacterial niche development. FEMS Microbiol. Rev. 2005, 29, 795-811. [CrossRef] [PubMed]

26. Hättenschwiler, S.; Tiunov, A.; Scheu, S. Biodiversity and litter decomposition in terrestrial ecosystems. Annu. Rev. Ecol. Evol. 2005, 36, 191-218. [CrossRef]

27. Fornara, D.A.; Tilman, D.; Hobbie, S.E. Linkages between plant functional composition, fine root processes and potential soil $\mathrm{N}$ mineralization rates. J. Ecol. 2009, 97, 48-56. [CrossRef]

28. Kerdraon, D.; Drewer, J.; Castro, B.; Wallwork, A.; Hall, J.; Sayer, E. Litter traits of native and non-native tropical trees influence soil carbon dynamics in timber plantations in panama. Forests 2019, 10, 209. [CrossRef]

29. Yang, Y.; Liu, S.; Chen, L.; Wang, H.; Lu, L. Short-term effects of manipulated throughfall reduction on the quantity and quality of litterfall in a Pinus massoniana plantation. Acta Ecol. Sin. 2018, 38, 4470-4478.

30. Zhou, X.; Wen, Y.; Goodale, U.M.; Zuo, H.; Zhu, H.; Li, X.; You, Y.; Yan, L.; Su, Y.; Huang, X. Optimal rotation length for carbon sequestration in Eucalyptus plantations in subtropical China. New For. 2017, 48, 609-627. [CrossRef]

31. Bao, S.D. Soil Agro-Chemistrical Analysis; China Agricultural Press: Beijing, China, 2000; pp. 1-495.

32. Evans, E.H.; Day, J.A.; Fisher, A.; Price, W.J.; Smith, C.M.M.; Tyson, J.F. Atomic spectrometry update. Advances in atomic emission, absorption and fluorescence spectrometry and related techniques. J. Anal. Atom. Spectrom. 2004, 19, 775. [CrossRef]

33. Reis, B.; Zagatto, E.; Jacintho, A. Merging zones in flow injection analysis: Part 4 . Simultaneous spectrophotometric determination of total nitrogen and phosphorus in plant material. Anal. Chim. Acta 1980, 119, 305-311. [CrossRef]

34. Liu, W.; Wu, J.; Fan, H.; Li, Y.; Yuan, Y.; Liao, Y.; Huang, R.; Hu, L.; Fang, H.; Guo, H. Carbon pools in an age sequence of Eucalyptus plantation forests. Ecol. Environ. Sci. 2013, 22, 12-17.

35. Liu, L.; Gundersen, P.; Zhang, T.; Mo, J. Effects of phosphorus addition on soil microbial biomass and community composition in three forest types in tropical China. Soil Biol. Biochem. 2012, 44, 31-38. [CrossRef]

36. You, Y.; Wang, J.; Huang, X.; Tang, Z.; Liu, S.; Sun, O.J. Relating microbial community structure to functioning in forest soil organic carbon transformation and turnover. Ecol. Evol. 2014, 4, 633-647. [CrossRef]

37. Dohrmann, R.; Kaufhold, S. Three new, quick CEC methods for determining the amounts of exchangeable calcium cations in calcareous clays. Clay Clay Miner. 2009, 57, 338-352. [CrossRef] 
38. Pan, G.; Chen, A. Comparison of methods for determination of cation exchange properties of different soils form southern China. Trop. Subtrop. Soil Sci. 1992, 1, 38-44.

39. Vance, E.D.; Brookes, P.C.; Jenkinson, D.S. An extraction method for measuring soil microbial biomass C. Soil Biol. Biochem. 1987, 19, 703-707. [CrossRef]

40. Brookes, P.C.; Landman, A.; Pruden, G.; Jenkinson, D.S. Chloroform fumigation and the release of soil nitrogen: A rapid direct extraction method to measure microbial biomass nitrogen in soil. Soil Biol. Biochem. 1985, 17, 837-842. [CrossRef]

41. Bossio, D.A.; Scow, K.M.; Gunapala, N.; Graham, K.J. Determinants of soil microbial communities: Effects of agricultural management, season, and soil type on phospholipid fatty acid profiles. Microb. Ecol. 1998, 36, 1-12. [CrossRef]

42. Wang, X.; Wang, X.; Zhang, W.; Shao, Y.; Zou, X.; Liu, T.; Zhou, L.; Wan, S.; Rao, X.; Li, Z.; et al. Invariant community structure of soil bacteria in subtropical coniferous and broadleaved forests. Sci. Rep. 2016, 6, 19071. [CrossRef]

43. Bossio, D.A.; Fleck, J.A.; Scow, K.M.; Fujii, R. Alteration of soil microbial communities and water quality in restored wetlands. Soil Biol. Biochem. 2006, 38, 1223-1233. [CrossRef]

44. Kourtev, P.S.; Ehrenfeld, J.G.; Haggblom, M. Exotic plant species alter the microbial community structure and function in the soil. Ecology 2002, 83, 3152. [CrossRef]

45. Lv, T.; Carvalho, P.N.; Zhang, L.; Zhang, Y.; Button, M.; Arias, C.A.; Weber, K.P.; Brix, H. Functionality of microbial communities in constructed wetlands used for pesticide remediation: Influence of system design and sampling strategy. Water Res. 2017, 110, 241-251. [CrossRef] [PubMed]

46. Dumontet, S.; Cavoski, I.; Ricciuti, P.; Mondelli, D.; Jarrar, M.; Pasquale, V.; Crecchio, C. Metabolic and genetic patterns of soil microbial communities in response to different amendments under organic farming system. Geoderma 2017, 296, 79-85. [CrossRef]

47. Liu, B.; Li, Y.; Zhang, X.; Wang, J.; Gao, M. Effects of chlortetracycline on soil microbial communities: Comparisons of enzyme activities to the functional diversity via Biolog EcoPlates ${ }^{\mathrm{TM}}$. Eur. J. Soil Biol. 2015, 68, 69-76. [CrossRef]

48. Saiya-Cork, K.R.; Sinsabaugh, R.L.; Zak, D.R. The effects of long term nitrogen deposition on extracellular enzyme activity in an Acer saccharum forest soil. Soil Biol. Biochem. 2002, 34, 1309-1315. [CrossRef]

49. Steinauer, K.; Tilman, D.; Wragg, P.D.; Cesarz, S.; Cowles, J.M.; Pritsch, K.; Reich, P.B.; Weisser, W.W.; Eisenhauer, N. Plant diversity effects on soil microbial functions and enzymes are stronger than warming in a grassland experiment. Ecology 2015, 96, 99-112. [CrossRef] [PubMed]

50. Wardle, D.A.; Bonner, K.I.; Nicholson, K.S. Biodiversity and plant litter: Experimental evidence which does not support the view that enhanced species richness improves ecosystem function. Oikos 1997, 79, $247-258$. [CrossRef]

51. Fanin, N.; Kardol, P.; Farrell, M.; Nilsson, M.; Gundale, M.J.; Wardle, D.A. The ratio of Gram-positive to Gram-negative bacterial PLFA markers as an indicator of carbon availability in organic soils. Soil Biol. Biochem. 2019, 128, 111-114. [CrossRef]

52. Chen, L.; Zeng, X.; Tam, N.F.; Lu, W.; Luo, Z.; Du, X.; Wang, J. Comparing carbon sequestration and stand structure of monoculture and mixed man-grove plantations of Sonneratia caseolaris and S. apetala in Southern China. For. Ecol. Manag. 2012, 284, 222-229. [CrossRef]

53. Rouhi-Moghaddam, E.; Hosseini, S.M.; Ebrahimi, E.; Tabari, M.; Rahmani, A. Comparison of growth, nutrition and soil properties of pure stands of Quercus castaneifolia and mixed with Zelkova carpinifolia in the Hyrcanian forests of Iran. For. Ecol. Manag. 2008, 255, 1149-1160. [CrossRef]

54. Binkley, D.; Campoe, O.C.; Gspaltl, M.; Forrester, D.I. Light absorption and use efficiency in forests: Why patterns differ for trees and stands. For. Ecol. Manag. 2013, 288, 5-13. [CrossRef]

55. Duan, W.; Ren, H.; Fu, S.; Wang, J.; Zhang, J.; Yang, L.; Huang, C. Community comparison and determinant analysis of understory vegetation in six plan-tations in South China. Restor. Ecol. 2010, 18, $206-214$. [CrossRef]

56. Zhang, K.; Dang, H.; Tan, S.; Wang, Z.; Zhang, Q. Vegetation community and soil characteristics of abandoned agricultural land and pine plantation in the Qinling Mountains, China. For. Ecol. Manag. 2010, 259, 2036-2047. [CrossRef] 
57. Hobbie, S.E.; Ogdahl, M.; Chorover, J.; Chadwick, O.A.; Oleksyn, J.; Zytkowiak, R.; Reich, P.B. Tree Species Effects on Soil Organic Matter Dynamics: The Role of Soil Cation Composition. Ecosystems 2007, 10, 999-1018. [CrossRef]

58. Bosatta, E.; Ågren, G.I. Theoretical analysis of microbial biomass dynamics in soils. Soil Biol. Biochem. 1994, 26, 143-148. [CrossRef]

59. Wolters, V.; Joergensen, R.G. Microbial carbon turnover in beech forest soils at different stages of acidification. Soil Biol. Biochem. 1991, 23, 897-902. [CrossRef]

60. Anderson, T.H.; Domsch, K.H. Ratios of microbial biomass carbon to total organic carbon in arable soils. Soil Biol. Biochem. 1989, 21, 471-479. [CrossRef]

61. Insam, H.; Domsch, K.H. Relationship between soil organic carbon and microbial biomass on chronosequences of reclamation sites. Microb. Ecol. 1988, 15, 177-188. [CrossRef]

62. Anderson, T.; Domsch, K.H. Carbon assimilation and microbial activity in soil. Z. Pflanz. Bodenkd. 1986, 149, 457-468. [CrossRef]

63. Cook, B.D.; Allan, D.L. Dissolved organic carbon in old field soils: Total amounts as a measure of available re-sources for soil mineralization. Soil Biol. Biochem. 1992, 24, 585-594. [CrossRef]

64. Lucas-Borja, M.E.; Candel, D.; Jindo, K.; Moreno, J.L.; Andrés, M.; Bastida, F. Soil microbial community structure and activity in monospecific and mixed forest stands, under Mediterranean humid conditions. Plant Soil 2012, 354, 359-370. [CrossRef]

65. Bauhus, J.; Paré, D.; Co Té, L. Effects of tree species, stand age and soil type on soil microbial biomass and its activity in a southern boreal forest. Soil Biol. Biochem. 1998, 30, 1077-1089. [CrossRef]

66. Feng, W.T.; Zou, X.M.; Schaefer, D. Above- and belowground carbon inputs affect seasonal variations of soil microbial bio-mass in a subtropical monsoon forest of southwest China. Soil Biol. Biochem. 2009, 41, 978-983. [CrossRef]

67. Yu, X.; Liu, X.; Zhao, Z.; Liu, J.; Zhang, S. Effect of monospecific and mixed sea-buckthorn (Hippophae rhamnoides) plantations on the structure and activity of soil microbial communities. PLoS ONE 2015, 10, e0117505. [CrossRef]

68. Balser, T.C.; Firestone, M.K. Linking Microbial Community Composition and Soil Processes in a California Annual Grassland and Mixed-Conifer Forest. Biogeochemistry 2005, 73, 395-415. [CrossRef]

69. Jian, S.; Li, J.; Chen, J.; Wang, G.; Mayes, M.A.; Dzantor, K.E.; Hui, D.; Luo, Y. Soil extracellular enzyme activities, soil carbon and nitrogen storage under nitrogen fertilization: A meta-analysis. Soil Biol. Biochem. 2016, 101, 32-43. [CrossRef]

70. Wittmann, C.; Kähkönen, M.A.; Ilvesniemi, H.; Kurola, J.; Salkinoja-Salonen, M.S. Areal activities and stratification of hydrolytic enzymes involved in the biochemical cycles of carbon, nitrogen, sulphur and phosphorus in podsolized boreal forest soils. Soil Biol. Biochem. 2004, 36, 425-433. [CrossRef]

71. Garland, J.L. Analysis and interpretation of community-level physiological profiles in microbial ecology. FEMS Microbiol. Ecol. 1997, 24, 289-300. [CrossRef]

72. Lehman, R.M.; Colwell, F.S.; Ringelberg, D.B.; White, D.C. Combined microbial community-level analyses for quality assurance of terrestrial subsurface cores. J. Microbiol. Meth. 1995, 22, 263-281. [CrossRef]

73. Zak, J.C.; Willig, M.R.; Moorhead, D.L.; Wildman, H.G. Functional diversity of microbial communities: A quantitative approach. Soil Biol. Biochem. 1994, 26, 1101-1108. [CrossRef]

(C) 2019 by the authors. Licensee MDPI, Basel, Switzerland. This article is an open access article distributed under the terms and conditions of the Creative Commons Attribution (CC BY) license (http://creativecommons.org/licenses/by/4.0/). 